\title{
CAN THE BATTLE BE WON? COMPAQ, THE SHAM TRANSACTION DOGTRINE, AND A CRITIQUE OF PROPOSALS TO COMBAT THE CORPORATE TAX SHELTER DRAGON
}

\author{
BRION D. GRABER ${ }^{\dagger}$
}

At a time when our Congress seems reluctant to seek to slay, or even injure, the corporate tax shelter dragon, our courts, and particularly the Tax Court, are building the walls of the fortress from such time-tested concepts as form versus substance and economic substance and risk of loss, to protect the fisc from being overrun and trampled by such tax shelters.

\section{INTRODUCTION}

Recently, corporate tax shelters have become one of the biggest areas of concern in the United States's tax policy. ${ }^{2}$ The Department of the Treasury ("Treasury"), Congressman Lloyd Doggett, "the Joint

† B.B.A. 1998, University of Michigan; J.D. Candidate 2001, University of Pennsylvania; C.P.A. 1999. I would like to acknowledge Robert G. Boehmer, Randy E. Preston, and the many other fine educators from whom I have learned so much. I would also like to thank my family and friends for supporting me in my chosen endeavors.

More generally, a special debt of gratitude is owed by all Americans to the tens of thousands of men and women employed by the Internal Revenue Service. These individuals do an extraordinary job each year of collecting the revenues that fund the services and activities of the federal government. Seldom, however, do people appreciate the magnitude or difficulty of this undertaking. Thank you for the job you do.

'Stefan F. Tucker, O! What Men Dare Do! What Men May Do! What Men Daily Do, Not Knowing What They Do!, NEwSL. (ABA Section of Taxation, Washington, D.C.), Winter 2000, at 21, 22.

${ }^{2}$ See Ryan J. Donmoyer, Debate Over Tax Shelters Dominates Finance Hearing, 2000 TAX NOTES TODAY 47-2, WL 2000 TNT 47-2 (quoting Lawrence H. Summers, Treasury Secretary, who has called corporate tax shelters "the most significant compliance problem in the Internal Revenue Code today'").

See Lawrence H. Summers, Tackling the Growth of Corporate Tax Shelters, Address to the Federal Bar Association (Feb. 28, 2000), in 2000 TAX NOTES TODAY 40-34, IIL 2000 TNT 40-34 (outlining the steps that should be taken in response to corporate tax shelters). Most importantly, on February 28, 2000, the Department of the Treasury issued temporary and proposed regulations intended to curb the abuse of corporate tax shelters. See T.D. $8875,2000-11$ I.R.B. 761 (requiring corporate tax shelter pro- 
Committee on Taxation, and the New York State Bar Association," among others, have all made proposals on how to deal with this growing problem that deprives the federal treasury of over ten billion dollars per year. ${ }^{7}$ Using the September 1999 Tax Court decision Compaq Computer Corp. v. Commissioner $^{8}$ as a framework, this Comment will ex-

moters to maintain customer lists); T.D. 8876, 2000-11 I.R.B. 753 (requiring corporate tax shelter registration); T.D. 8877, 2000-11 I.R.B. 747 (requiring taxpayer disclosure of participation in corporate tax shelters); see also DEPARTMENT OF THE TREASURY, THE PROBLEM OF CORPORATE TAX SHELTERS: DISCUSSION, ANALYSIS AND LEGISLATTVE PROPOSALS (1999) [hereinafter TREASURY WHITE PAPER] (providing background on the corporate tax shelter problem and making proposals to solve it).

${ }^{4}$ See Abusive Tax Shelter Shutdown Act of 1999, H.R. 2255, 106th Cong. (1999) (attempting to eliminate abusive corporate tax shelters).

${ }^{5}$ See JoInt COMmttee on TaXation, Study of Present-Law Penalty and INTEREST PROVISIONS AS REQUIRED BY SECTION 3801 OF THE INTERNAL REVENUE SERVICE RESTRUCTURING AND REFORM ACT OF 1998 (INCLUDING PROVISIONS RELATING TO CORPORATE TAX SHELTERS) (1999) [hereinafter JCT PROPOSAL] (making suggestions to reduce corporate tax shelter activity).

${ }^{6}$ See Tax Section, New York State Bar Ass'n, Comments on the Administration's Corporate Tax Shelter Proposals, 83 TAX NoTES 879 (1999) (proposing ways to combat the corporate tax shelter problem).

${ }^{7}$ See David R. Francis, Bye-Bye Comporate Tax Revenues, CHRISTIAN SCI. MONITOR, Nov. 3, 1999, at 8, 8 ("Lost revenue in fiscal 1999 alone could be $\$ 13$ billion to $\$ 24$ billion ...."); Janet Novack \& Laura Saunders, The Hustling of X-Rated Shelters, FORBES, Dec. 14, 1998, at 198, 199 ("These unintended tax breaks are saving corporate buyers up to $\$ 10$ billion in tax a year.... [The tax shelter] business is booming and there's nothing to slow it down ...."). But see Ian Springsteel, Helter Shelter, CFO, June 1, 1999, at 81,1999 WL 8850916 (stating that the accuracy of the claim that corporate tax shelters are a $\$ 10$ billion per year problem has never been proven). A fairly intense debate has raged over the amount of tax revenue, if any, that has actually been lost due to corporate tax shelters. See, e.g., Kenneth J. Kies, Corporate Tax Base Erosion is Still Unproven, 86 TAX NoTES 1445,1446 (2000) ("I stand by my contention that there is no convincing data that would indicate that 'corporate tax shelters' are eroding the corporate income tax base."); Jasper L. Cummings, Jr. \& Alan J. Swirski, Interview With Dr. Martin A. Sullivan, NEwSL. (ABA Section of Taxation, Washington, D.C.), Spring 2000, at 20,20 (asserting that there has been "a recent decline in corporate tax receipts relative to book income" and that an increase in the use of corporate tax shelters is one likely explanation).

Nevertheless, it is generally accepted among tax professionals that there is a corporate tax shelter problem. See Donmoyer, supra note 2, ("[M] ost tax professional groups agree that 'there is a tax shelter problem, make no mistake about that." (quoting Peter L. Faber, a partner at McDermott, Will \& Emery)). Furthermore, the frequency with which corporate tax shelters are currently marketed to companies, the sizeable fees promoters charge for many of these tax shelters, and the amount of tax benefits at issue in recent corporate tax shelter cases all provide substantial anecdotal evidence of a drain on corporate tax receipts. If companies could not greatly reduce their tax liability by participating in corporate tax shelters, why would companies ever buy tax shelters? If companies were not buying, why would promoters continue to devote resources to creating and marketing tax shelters?

${ }^{8} 113$ T.C. 214 (1999). 
amine the merits of these recent proposals, giving due consideration to traditional, primarily judicial, solutions.

Part I explains the facts of Compaq, focusing on the specific corporate tax shelter at issue in the case. The transaction, in essence, involved Compaq Computer Corp. ("Compaq") purchasing stock of a foreign corporation on which a dividend had been declared but not yet paid. After the dividend record date, Compaq sold the stock at a price equal to its original purchase price less the amount of the net dividend. Compaq was required to pay tax to a foreign country on the receipt of the dividend, and thus was able to claim a foreign tax credit. The opportunity to claim the tax credit was the goal of the entire transaction, and allowed Compaq to reduce its tax liability from unrelated transactions on a dollar per dollar basis.

Part II provides an analysis of the sham transaction doctrine that is crucial to understanding both the Compaq opinion and the merits of the proposed solutions to the corporate tax shelter problem. The courts have developed the sham transaction doctrine over the last sixty-five years to distinguish those transactions that should be recognized for tax purposes from those that should not, based primarily on whether the transaction possessed economic substance or a business purpose absent its tax effects. The analysis explains what factors the courts examine in making that determination.

With the background provided in Part II, Part III returns to Compaq to examine the Tax Court's opinion. The Tax Court relied heavily on the sham transaction doctrine in concluding that the transaction was an economic sham lacking both nontax economic substance and a nontax business purpose. The opinion also explains why an accuracyrelated penalty was properly assessed against Compaq for its tax return reporting of the transaction.

Finally, Part IV examines several of the primary proposals to combat corporate tax shelters and identifies those that are constructive to pursue. Although not the principal focus of this Comment, special attention is given to discussing Treasury's temporary and proposed regulations because they are the most authoritative measure taken to date against corporate tax shelters.

This Comment asserts that requiring greater disclosure by corporations of potentially abusive transactions has the greatest capacity to curb corporate tax shelter abuse. Treasury is currently employing this strategy in the temporary and proposed regulations. Although the actual impact of the temporary and proposed regulations is not yet known, increased disclosure should allow the Commissioner of the In- 
ternal Revenue Service ("Commissioner") to expend his resources examining the merits of the disclosed transactions and disallowing those that are abusive, instead of aimlessly searching for potentially abusive transactions in the first place. Such a change should put an immediate end to many of the corporate tax shelters, which derive their value from the fact that they are unlikely ever to be discovered, rather than from any solid legal basis.

In addition, modifying the existing penalty structure would be beneficial, but only if done in conjunction with the new disclosure requirements. Modifications to the penalty system would provide additional incentives for taxpayers, whose compliance is voluntary, to act within the law. A similar benefit could be achieved by imposing an excise tax on the fees of corporate tax shelter promoters and advisors arising from nondisclosed corporate tax shelters.

Other proposals, such as codifying the existing judicial anti-taxavoidance doctrines and providing consequences for tax-indifferent parties who participate in corporate tax shelters, however, are not beneficial and may actually exacerbate the corporate tax shelter problem by reopening closed loopholes or creating new ones. At its best, codification would simply repeat current, well established judicial doctrine. At its worst, codification would increase tax complexity and uncertainty for taxpayers and retard the ability of the Commissioner and the courts to enforce the tax laws. These proposals should not be pursued.

\section{THE FACTS OF COMPAQ}

Compaq's desire to minimize the tax liability resulting from a sizeable long-term capital gain on the July 1992 sale of stock it held in a publicly traded, nonaffiliated computer company provided the impetus for the transaction at issue in Compaq. ${ }^{9}$ Shortly after the stock sale, Twenty-First Securities Corp. ("Twenty-First"), an investment firm, solicited Compaq's participation in a transaction designed to shield part of the long-term capital gain from tax. ${ }^{10}$ During the first meeting on September 15, 1992, Twenty-First presented two suggested transactions to James J. Tempesta, an assistant treasurer at Compaq, and John M. Foster, Compaq's treasurer: a Dividend Reinvestment

${ }^{9}$ See id. at 215 (1999) (discussing the sale of Conner Peripherals, Inc. stock).

${ }^{10} \mathrm{Id}$. 
Arbitrage Program and an ADR arbitrage. ${ }^{11}$ The day after the meeting, Compaq notified Twenty-First of its decision to pursue the ADR transaction. ${ }^{12}$ Compaq made this decision based on a telephone conversation with a single Twenty-First reference and a review of a spreadsheet provided by Twenty-First, but without performing even a cash flow analysis of the transaction. ${ }^{13}$

Immediately upon learning of Compaq's decision, Twenty-First began to execute the ADR transaction. ${ }^{14}$ The only guidance from Compaq during the transaction concerned the number of shares to purchase and the suggestion that the ADRs used should be those of Royal Dutch Petroleum Co. ("Royal Dutch"). ${ }^{15}$ Twenty-First decided from whom to purchase the ADRs, how large each trade should be, and "the market prices to be paid," but did not discuss these details with anyone from Compaq. ${ }^{16}$

Ultimately, Twenty-First ordered the purchase of ten million ADR shares of Royal Dutch on Compaq's behalf. The shares were purchased "cum dividend" and resold "ex dividend" in twenty-three separate cross trades that were completed in approximately one hour. ${ }^{17}$ All ten million shares were purchased from a long-time client of Twenty-First, and then immediately resold to that same company. ${ }^{18}$ The purchase cross trades were settled on September 17, pursuant to special "next day" settlement terms allowed by the New York Stock Exchange. ${ }^{19}$ The resale cross trades were settled on September 21, pursuant to regular settlement rules. ${ }^{20}$ Arranging the settlements in this way allowed Compaq to be the shareholder of record of the ADRs on the dividend record date, thereby entitling Compaq to receive the declared dividend. ${ }^{\text {II }}$

When Royal Dutch paid the dividend to its United States resident

"An ADR (American Depository Receipt) is a trading unit issued by a trust which represents ownership of stock in a foreign corporation that is deposited with the trust. ADR's are the customary form of trading foreign stocks on U.S. stock exchanges." Id.

I2 Id. at 216.

is Id.

14 at 217.

1. Brief for Respondent: “ADR” Issue at 8, Compaq (No. 24238-96).

I". Compaq, 113 T.C. at 217.

${ }^{17}$ An ADR purchased cum dividend includes the right to receive a dividend that has been declared, while one purchased ex dividend does not include that right. Id. at 215-16.
Is Id. at 217.
'Id. at 218.
"II $I$.
Id. at 219 . 
shareholders, including Compaq, it withheld and paid over to the appropriate taxing authorities of the Netherlands fifteen percent of the declared dividend, as required by law. ${ }^{22}$

Compaq reported a short-term capital loss $(\$ 20,652,816)$ from the purchase and resale of the ADRs on its 1992 federal income tax return. $^{23}$ Compaq also reported dividend income $(\$ 22,546,800)$ and, most importantly, claimed a foreign tax credit $(\$ 3,382,050)$ as a result of the transaction. ${ }^{24}$

\section{TRADITIONAL SHAM TRANSACTION ANALYSIS}

Americans have never found great fulfillment in paying taxes. ${ }^{25}$ Consequently, they seek to minimize their tax liability by carefully structuring their personal and business dealings to take full advantage of the benefits available in the tax laws. The courts have recognized this fact and acknowledged the legality of such efforts for more than sixty years. ${ }^{26}$ Judge Learned Hand commented on this principle:

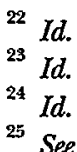

${ }^{25}$ See generally CHARLES ADAMS, THOSE DIRTY ROTTEN TAXES: THE TAX REvOlTS THAT BULT AMERICA (1998) (describing a number of revolts staged by Americans in response to various taxes). The distaste for paying taxes is not unique to America, however, and existed long before the country declared its independence from England in 1776. See, e.g., ADAMS, supra, at 30-31 (discussing the effect of disfavored taxes in Great Britain, Spain, the Netherlands, and France); SHELley L. DAVIS, UNBRIDLED POWER: INSIDE THE SECRET CULTURE OF THE IRS 19 (1997) ("[T]ax collectors have never been popular, not in the days of the pharaohs, not during the reign of the Caesars, nor during Charlemagne's time, or Napoleon's, or, for that matter, Savonarola's."). In the Bible, for example, tax collectors are categorized with prostitutes and sinners. See Matthew 9:10 ("And as he sat at table in [Matthew's] house, behold, many tax collectors and sinners came and sat down with Jesus and his disciples."); id. 21:31 ("Jesus said to them, 'Truly, I say to you, the tax collectors and the harlots go into the kingdom of God before you."').

${ }^{26}$ See, e.g., Frank Lyon Co. v. United States, 435 U.S. 561, 580 (1978) ("The fact that favorable tax consequences were taken into account by [the taxpayer] on entering into the transaction is no reason for disallowing those consequences. We cannot ignore the reality that the tax laws affect the shape of nearly every business transaction."); Gregory v. Helvering, 293 U.S. 465, 469 (1935) ("The legal right of a taxpayer to decrease the amount of what otherwise would be his taxes, or altogether avoid them, by means which the law permits, cannot be doubted."); Helvering v. Gregory, 69 F.2d 809, 810 (2d Cir. 1934) ("Any one may so arrange his affairs that his taxes shall be as low as possible; he is not bound to choose that pattern which will best pay the Treasury; there is not even a patriotic duty to increase one's taxes."), affd, 293 U.S. 465 (1935); ACM P'ship v. Comm'r, 73 T.C.M. (CCH) 2189, 2215 (1997) ("We do not suggest that a taxpayer refrain from using the tax laws to the taxpayer's advantage."), aff'd in part, rev'd in part, 157 F.3d 231 (3d Cir. 1998), cert. denied, 526 U.S. 1017 (1999); 
Over and over again courts have said that there is nothing sinister in so arranging one's affairs as to keep taxes as low as possible. Everybody does so, rich or poor; and all do right, for nobody owes any public duty to pay more than the law demands: taxes are enforced exactions, not voluntary contributions. To demand more in the name of morals is mere cant. ${ }^{27}$

That is not to imply, however, that everything that taxpayers do must be accepted by the Commissioner and the courts when applying the tax laws. ${ }^{28}$ Over the years, several related judicial doctrines have arisen that limit taxpayers' ability to successfully engage in certain tax avoidance transactions. Principal among these is the sham transaction doctrine, which comprises both the economic substance and business purpose doctrines.

It is a well accepted principle that application of the tax laws depends on the substance of a transaction and not its form. ${ }^{29}$ To look only at form would be to "exalt artifice above reality and to deprive the statutory provision in question of all serious purpose. ${ }^{30}$ Furthermore, it would hinder the "effective administration of the tax policies of Congress."

The Commissioner is therefore generally free to examine the substance of a transaction and then decide that either the transaction's

Rice's Toyota World, Inc. v. Comm'r, 81 T.C. 184, 196 (1983) ("Taxpayers are generally free to structure their business transactions as they please, though motivated by tax avoidance .... "), affd in part, rev'd in part, 752 F.2d 89 (4th Cir. 1985).

${ }^{27}$ Comm'r v. Newman, 159 F.2d 848, 850-51 (2d Cir. 1947) (Hand, J., dissenting).

2* See Saviano v. Comm'r, 765 F.2d 643, 654 (7th Cir. 1985) ("The freedom to arrange one's affairs to minimize taxes does not include the right to engage in financial fantasies with the expectation that the Internal Revenue Service and the courts will play along.").

24 See, e.g., Comm'r v. Court Holding Co., 324 U.S. 331, 334 (1945) ("The incidence of taxation depends upon the substance of a transaction."); Helvering v. F. \& R. Lazarus \& Co., 308 U.S. 252, 255 (1939) ("In the field of taxation, administrators of the laws, and the courts, are concerned with substance and realities, and formal written documents are not rigidly binding."); Gregary, 293 U.S. at 470 (disallowing the tax benefits arising from a transaction because " $[t]$ he whole undertaking, though conducted according to the terms of [the Internal Revenue Code], was in fact an elaborate and devious form of conveyance masquerading as a corporate reorganization, and nothing else"); Saviano, 765 F.2d at 654 ("The Commissioner and the courts are empowered, and in fact duty-bound, to look beyond the contrived forms of transactions to their economic substance and to apply the tax laws accordingly."); Comm'r v. Ashland Oil \& Refining Co., 99 F.2d 588, 591 (6th Cir. 1938) ("[T]axation is an intensely practical matter, and ... the substance of the thing done and not the form it took must govern.").

Gregon; 293 U.S. at 470; see also Higgins v. Smith, 308 U.S. 473, 477-78 (1940) ("To hold otherwise would permit the schemes of taxpayers to supersede legislation in the determination of the time and manner of taxation.").

$\$ 1$ Court Holding Co., 324 U.S. at 334. 
form should be respected because it reflects its substance, or the form should be disregarded because it does not reflect the substance of the transaction. ${ }^{32}$ A transaction may be disregarded for tax purposes if it is a sham transaction. ${ }^{38}$ There exists, however, ambiguity as to what exactly it means for a transaction to be a sham. Some court decisions include in their definition transactions that never actually occurred, transactions that had no economic substance, and transactions that had no business purpose, while other decisions distinguish among these categories. ${ }^{34}$ Regardless of the label attached, the result is that transactions falling within any of these categories will not be recognized for tax purposes.

For purposes of this Comment, transactions that never actually occurred will be referred to as "factual shams." Little discussion is necessary to explain why factual shams are not recognized. The tax laws do not permit taxpayers to realize tax benefits without actually engaging in the transactions that give rise to them. ${ }^{35}$ It is irrelevant that Congress has provided tax benefits for similar, but real, transactions. ${ }^{36}$ Allowing tax benefits to accrue from factual shams would create a much greater potential for abuse because the taxpayer has " $[t] h e$

${ }^{32}$ See Higgins v. Smith, 308 U.S. at 477 ("The Government may look at actualities and upon determination that the form employed for doing business or carrying out the challenged tax event is unreal or a sham may sustain or disregard the effect of the fiction as best serves the purposes of the tax statute."); Spector v. Comm'r, 641 F.2d 376, 381 (5th Cir. Unit A Apr. 1981) ("Just as the Commissioner in determining income tax liabilities may look through the form of a transaction to its substance, so, as a general rule, may he bind a taxpayer to the form in which the taxpayer has cast a transaction." (citations omitted)).

${ }^{33}$ See United States v. Wexler, 31 F.3d 117, 122 (3d Cir. 1994) (noting the general rule that a sham transaction is ignored for federal tax purposes); Lerman v. Comm'r, 939 F.2d 44, 45 (3d Cir. 1991) (finding that a sham transaction "is not recognized for federal taxation purposes").

${ }^{34}$ See Sochin v. Comm'r, 843 F.2d 351, 352-54 (9th Cir. 1988) (identifying business purpose and economic substance as factors to be considered in determining whether a transaction is a factual sham); Yosha v. Comm'r, 861 F.2d 494, 500 (7th Cir. 1988) (distinguishing between two types of shams: those where there were no transactions, and those where the transactions really occurred but had no economic substance); Rice's Toyota World, Inc. v. Comm'r, 81 T.C. 184, 200 (1983) (noting that some "courts reserve the term 'sham' for a more narrow situation in which the transaction used by the taxpayer is, for example, merely a paper transaction or a 'fake' transmission of money"), aff'd in part, rev'd in part, 752 F.2d 89 (4th Cir. 1985).

${ }^{35}$ See Enrici v. Comm'r, 813 F.2d 293, 296 (9th Cir. 1987) (per curiam) (disallowing claimed tax benefits because "the parties were merely rigging paper prices, losses, and gains to effectuate a sale of generated tax losses").

${ }^{36}$ See id. ("The fact that Congress may have permitted similar tax advantages to be obtained from real commodities straddles does not make the losses from these sham transactions deductible."). 
absolute power to manipulate and dictate the price and timing of the artificial transactions, [resulting in] larger and surer tax advantages with much less economic risk" for the taxpayer than if he entered into real transactions. ${ }^{37}$

From a doctrinal standpoint, concentrating on what will be referred to as "economic sham" transactions is more interesting. Economic sham analysis is primarily concerned with ascertaining "whether the transaction had any practical economic effects other than the creation of income tax losses." The Supreme Court has stated that a transaction should be respected for tax purposes when there is "a genuine multiple-party transaction with economic substance which is compelled or encouraged by business or regulatory realities, is imbued with tax-independent considerations, and is not shaped solely by tax-avoidance features that have meaningless labels attached." ${ }^{39}$ Courts typically focus on two factors in determining whether a transaction is an economic sham: (1) whether the transaction had economic substance beyond the production of tax benefits (an objective analysis), and (2) whether there was a nontax business purpose (a subjective analysis). "However, these distinct aspects of the economic sham inquiry do not constitute discrete prongs of a 'rigid two-step analysis,' but rather represent related factors both of which inform the analysis of whether the transaction had sufficient substance, apart from its tax consequences, to be respected for tax purposes." The fact that a transaction lacks a business purpose, or alternatively, lacks economic substance, is not conclusive evidence of a sham transaction. ${ }^{42}$

${ }^{17}$ Id.

Sochin, 843 F.2d at 354.

"Frank Lyon Co. v. United States, 435 U.S. 561, 583-84 (1978).

4' See ACM P'ship v. Comm'r, 157 F.3d 231, 247 (3d Cir. 1998) (stating that whether a transaction is an economic sham depends on both a subjective test and an objective test), cert. denied, 526 U.S. 1017 (1999); Sochin, 843 F.2d at 354 (noting that courts typically focus on whether a transaction had a nontax business purpose and economic substance to determine if it is a sham); Rice's Toyota World, Inc. v. Comm'r, 752 F.2d 89, 91 (4th Cir. 1985) ("To treat a transaction as a sham, the court must find that the taxpayer was motivated by no business purposes other than obtaining tax benefits in entering the transaction, and that the transaction had no economic substance....").

41 ACM PShip, 157 F.3d at 247; see also Sochin, 843 F.2d at 354 ("[W]e did not intend our decision in Bail Bonds to outline a rigid two-step analysis. Instead, the consideration of business purpose and economic substance are simply more precise factors to consider in the application of this court's traditional sham analysis . . . ").

4: See Packard v. Comm'r, 85 T.C. 397, 417 (1985) ("A taxpayer's failure to establish that a transaction was motivated by a business purpose rather than by tax avoid- 


\section{A. Economic Substance Doctrine}

The economic substance doctrine seeks to objectively determine if a transaction possessed any real, nontax economic benefit. ${ }^{43}$ In making this decision, the doctrine only requires that the transaction be one "that some people enter into without a tax motive, even though the people fighting to defend the tax advantages of the transaction might not or would not have undertaken it but for the prospect of such advantages-may indeed have had no other interest in the transaction." In evaluating a transaction for economic substance, the courts have frequently concentrated on whether the transaction had a reasonable possibility of profit without considering its tax benefits. ${ }^{45}$ Another important related consideration is whether the taxpayer was exposed to any economic risk by engaging in the transaction. ${ }^{46}$ When

ance is not conclusive ... that the transaction was a sham. Rather, if ... a reasonable possibility of profit existed apart from tax benefits, the transaction will not be classified as a sham."); Rice's Toyota World, Inc. v. Comm'r, 81 T.C. 184, 203 n.17 (1983) ("Once business purpose is established, the transaction should not be classified a 'sham.' A finding of no business purpose, however, is not conclusive evidence of a sham transaction. The transaction will still be valid if it possesses some modicum of economic substance."), affd in part, rev'd in part, 752 F.2d 89 (4th Cir. 1985).

${ }^{43}$ See ACM P'Ship, 157 F.3d at 248 ("In assessing the economic substance of a taxpayer's transactions, the courts have examined 'whether the transaction has any practical economic effects other than the creation of income tax losses'...." (quoting Jacobson v. Comm'r, 915 F.2d 832, 837 (2d Cir. 1990)); Sochin, 843 F.2d at 354 (articulating the objective analysis as whether "the transaction had 'economic substance' beyond the generation of tax benefits"); Rice's Toyota World, Inc., 752 F.2d at 94 (stating that the economic substance inquiry is an objective inquiry into whether the transaction produced any nontax benefit).

${ }^{44}$ Yosha v. Comm'r, 861 F.2d 494, 499 (7th Cir. 1988); see also Rice's Toyota World, Inc., 752 F.2d at 96 (" $[\mathrm{T}]$ he court may not ignore transactions that have economic substance even if the motive for the transaction is to avoid taxes.").

${ }^{45}$ See, e.g., Rice's Toyota World, Inc., 752 F.2d at 94 ("[T] he economic substance inquiry ... requires an objective determination of whether a reasonable possibility of profit from the transaction existed apart from tax benefits."); Sheldon v. Comm'r, 94 T.C. 738,759 (1990) (noting that "where transactions are analyzed regarding their economic substance, the focus is upon profit objective or the potential for profit"); Packard, 85 T.C. at 417 (" $[\mathrm{I}] \mathrm{f}$ an objective analysis of the transaction indicates that a reasonable possibility of profit existed apart from tax benefits, the transaction will not be classified as a sham.").

${ }^{46}$ See Yosha, 861 F.2d at 500 (stating that transactions that do not involve market risk are not economically substantial transactions); Fender v. United States, 577 F.2d 934, 936 (5th Cir. 1978) (stating that whether the taxpayers were entitled to a loss deduction depended on whether they faced "a real risk of not being able to ... recover the apparent loss" arising from the transaction); Heltzer v. Comm'r, 62 T.C.M. (CCH) 518,529 (1991) ("Commodity trading lacks economic substance where it is virtually risk-free ...."). 
appropriate, the courts have considered other factors, such as the reasonableness of the sales price and adherence to contractual terms. ${ }^{47}$

\section{Profit Potential}

\section{a. Generally}

On numerous occasions courts have declared transactions to be shams because they lacked a possibility for profit. ${ }^{48}$ In Sheldon $v$. Commissioner, involving the simultaneous purchase of Treasury Bills ("TBills") and the entrance into repurchase agreements ("repos") for those T-Bills, the court stated that the partnership did not have "any potential for future profit" because it was obligated to pay higher rates of interest under the repos than it received on the T-Bills. ${ }^{51}$ Furthermore, although some of the repos to maturity did not have this char-

${ }^{47}$ See Frank Lyon Co. v. United States, 435 U.S. 561, 582-83 (1978) (listing a number of factors that the Court felt were meaningful in determining the "substance and economic realities of the transaction"); Bealor v. Comm'r, 72 T.C.M. (CCH) 730, 766 (1996) (same); Arrowhead Mountain Getaway, Ltd. v. Comm'r, 69 T.C.M. (CCH) 1805, 1817 (1995) (same), affd mem., 119 F.3d 5 (9th Cir. 1997); Levy v, Comm'r, 91 T.C. 838,856 (1988) (same); Rose v. Comm'r, 88 T.C. 386, 410-11 (1987) (same), affd, 868 F.2d 851 (6th Cir. 1989).

${ }^{4 x}$ See, e.g., Rice's Toyota World, Inc., 752 F.2d at 9495 (finding that a transaction lacked economic substance because the residual value of the equipment involved in the transaction "was not sufficient to earn [the taxpayer] a profit"); Glass v. Comm'r, 87 T.C. 1087, 1157 (1986) (describing an option straddle transaction that was found to lack economic substance as having produced a loss in year one and a gain in year two that was approximately equal to the year one loss), affd sub nom. Herrington $\mathrm{v}$. Comm'r, 854 F.2d 755 (5th Cir. 1988), Yosha v. Comm'r, 861 F.2d 494 (7th Cir. 1988), Ratliff v. Comm'r, 865 F.2d 97 (6th Cir. 1989), Kirchman v. Comm'r, 862 F.2d 1486 (11th Cir. 1989), Keane v. Comm'r, 865 F.2d 1088 (9th Cir. 1989), Killingsworth v. Comm'r, 864 F.2d 1214 (5th Cir. 1989), Friedman v. Comm'r, 869 F.2d 785 (4th Cir. 1989), Dewees v. Comm'r, 870 F.2d 21 (1st Cir. 1989), Kielmar v. Comm'r, 884 F.2d 959 (7th Cir. 1989), Lee v. Comm'r, 897 F.2d 915 (8th Cir. 1989), Bohrer v. Comm'r, 945 F.2d 344 (10th Cir. 1991); Aiken Indus., Inc. v. Comm'r, 56 T.C. 925, 934 (1971) (declaring a transaction to lack economic substance because it produced "the same inflow and outflow of funds").

14 94 T.C. 738 (1990).

"In a repo, a seller of a security (a funds borrower) transfers the security to a buyer (a funds lender) under an arrangement whereby the securities seller agrees to repurchase the security on a specified date (often the next day) at a specified price, and the securities buyer agrees to resell the security back to the seller. From the perspective of the buyer, the transaction is a reverse repurchase agreement (reverse repo). Repos serve the function of secured borrowings and loans, although they are denominated as sales and resales.

Charles W. Mooney, Jr., Beyond Negotiability: A New Model for Transfer and Pledge of Interests in Securities Controlled by Intermediaries, 12 CARDOZO L. REV. 305, 324 n.51 (1990).

Sheldon, 94 T.C. at 763. 
acteristic (that is, they were marginally profitable), economic substance was still lacking because they served merely to reduce the already established losses resulting from the prior repos. ${ }^{52}$

The amount of profit potential that a transaction must have in order to possess economic substance is an unsettled question. Some court opinions contain language indicating that any profit potential is sufficient. $^{53}$ Other opinions require the profit potential to be more than nominal. ${ }^{54}$ There are also numerous cases that compare the profit potential to the tax benefits generated by the transaction, although no specific threshold ratio is mentioned. ${ }^{55}$ Much of the uncertainty as to the amount of profit and the profit/tax benefit ratio necessary for a transaction to be deemed to possess economic substance is due to the fact that the cases tend to fall at the extremes, with the transaction either lacking any possibility of profit, ${ }^{56}$ or requiring sig-

${ }^{52} I d$.

${ }^{53}$ See ACM P'ship v. Comm'r, 73 T.C.M. (CCH) 2189, 2217 (1997) (holding that economic substance "will not be found unless there was a reasonable expectation that the nontax benefits would be at least commensurate with the transaction costs"), affd in part, rev'd in part, 157 F.3d 231 (3d Cir. 1998), cert. denied, 526 U.S. 1017 (1999); Rice's Toyota World, Inc. v. Comm'r, 81 T.C. 184, 207 (1983) ("As shown by the financial calculations and using even the most optimistic forecasts, the transaction in the case before us could not prove profitable."), aff'd in part, rev'd in part, 752 F.2d 89 (4th Cir. 1985); Aiken Indus., Inc., 56 T.C. at 934 (stating that a transaction lacked economic substance where a corporation "obtained exactly what it gave up in a dollar-for-dollar exchange. Thus, it was committed to pay out exactly what it collected, and it made no profit on the [transaction]....").

${ }^{54}$ See Sheldon, 94 T.C. at 767 (acknowledging that a few of the transactions had a small potential for gain, but dismissing the amounts as "nominal" and "relatively insignificant"); Estate of Thomas v. Comm'r, 84 T.C. 412,440 n.52 (1985) ("Since the potential profit here was more than de minimis, we are satisfied that [the taxpayers] should prevail.").

${ }^{55}$ See, e.g., Knetsch v. United States, 364 U.S. 361, 366 (1960) (noting that the taxpayer incurred a net cash outflow of over $\$ 90,000$ by borrowing money at a higher rate than the purchased annuity paid, but sought a tax reduction of over $\$ 230,000$ ); Sheldon, 94 T.C. at 768 ("The potential for 'gain' here ... is infinitesimally nominal and vastly insignificant when considered in comparison with the claimed deductions."); Glass v. Comm'r, 87 T.C. 1087, $1157(1986)$ ("While the tax losses anticipated were very substantial, the economic gains, if any, and losses were, by comparison, very small."), affd sub nom. Herrington v. Comm'r, 854 F.2d 755 (5th Cir. 1988), Yosha v. Comm'r, 861 F.2d 494 (7th Cir. 1988), Ratliff v. Comm'r, 865 F.2d 97 (6th Cir. 1989), Kirchman v. Comm'r, 862 F.2d 1486 (11th Cir. 1989), Keane v. Comm'r, 865 F.2d 1088 (9th Cir. 1989), Killingsworth v. Comm'r, 864 F.2d 1214 (5th Cir. 1989), Friedman v. Comm'r, 869 F.2d 785 (4th Gir. 1989), Dewees v. Comm'r, 870 F.2d 21 (1st Cir. 1989), Kielmar v. Comm'r, 884 F.2d 959 (7th Cir. 1989), Lee v. Comm'r, 897 F.2d 915 (8th Cir. 1989), Bohrer v. Comm'r, 945 F.2d 344 (10th Cir. 1991).

${ }^{56}$ See, e.g., Rice's Toyota World, Inc., 81 T.C. at 205-06 (reviewing calculations that showed, when ignoring tax benefits, that the taxpayer could not recover his initial investment in the transaction). 
nificantly more cash expenditures than tax benefits generated..$^{57}$ It is unlikely that the courts will set more specific standards until they are presented with closer cases.

\section{b. Discounted Value}

In Hilton $v$. Commissioner, ${ }^{58}$ the Tax Court-having already determined that the projections of the taxpayer's expert were "fatally defective"-stated in dicta that profit potential should be determined on a discounted, or present value, ${ }^{59}$ basis. ${ }^{60}$ When the Ninth Circuit affirmed Hilton, however, it disavowed the discounted value approach, fearing it was a dangerous step toward requiring a minimum rate of return. ${ }^{\text {i1 }}$ The Tax Court also distanced itself from its Hilton decision in a subsequent case in which, although the parties had not raised the issue, it refused to use the discounted value approach. ${ }^{62}$ The court addressed:

whether, in determining the economic viability of the instant transaction, we are required to discount the expected residual value of the equipment back to 1975 dollars. In the absence of statutory mandate, we decline to do so. While we are aware of our footnote 23 in Hilton, we note that the method employed therein was dictum in the context of circumstances bordering on the egregious.

Moreover, we do not feel competent, in the absence of legislative guidance, to require that a particular return must be expected before a "profit" is recognizable, the necessary conclusion to be drawn if we were

${ }^{37}$ See, e.g., Lemmen v. Comm'r, 77 T.C. 1326, 1345-46 (1981) (noting that the taxpayer could realize a net tax savings of only $\$ 27,847$ in exchange for a cash outlay of $\$ 51,594)$.

74 T.C. 305 (1980), affd per curiam, 671 F.2d 316 (9th Cir. 1982).

Determining profit on a present value basis takes into account the time value of money. The general idea is that $\$ 1$ received today is worth more than $\$ 1$ received a year from now because the $\$ 1$ received today can be invested and can earn a return.

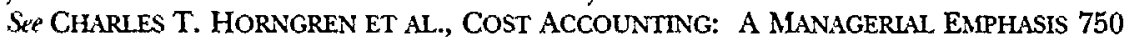
(10th ed. 2000) (defining "time value of money"). For example, if Ronald receives $\$ 100$ on January 1,2000 , he can invest that amount in T-Bills that pay, let us assume, $6 \%$ interest. On January 1, 2001, Ronald will have $\$ 106-$ his original $\$ 100$ plus $\$ 6$ in interest. This logic works in both directions. For example, if Molly has the opportunity to purchase an investment that will pay her $\$ 500$ on January 1,2001 , she will only be willing to pay approximately $\$ 472$ for that investment on January 1,2000 , again assuming that her next best use of the money is to purchase T-Bills that pay $6 \%$ interest.

Hilton, 74 T.C. at $353 \&$ n.23.

"1 See Hilton v. Comm'r, 671 F.2d 316, 317 (9th Cir. 1982) (per curiam) ("We deem the ... rate [used by the Tax Court to discount to present value] to be for illustrative purposes only. No suggestion of a minimum required rate of return is made.").

iz Estate of Thomas v, Comm'r, 84 T.C. 412,440 n.52 (1985). 
to discount residual value.... Our sole task here is to determine whether a profit was reasonably likely on these facts in order to find that tax avoidance was not the sole motivation for the transaction. Since the potential profit here was more than de minimis, we are satisfied that petitioners should prevail. ${ }^{63}$

Despite the language in Estate of Thomas, by 1997 the Tax Court had apparently renewed its belief in the discounted value approach when it declared that "[the taxpayer] could not have achieved a nonnegative net present value under any reasonable forecast of future interest rates." ${ }^{64}$ The Third Circuit also embraced the discounted value approach when it affirmed the ACM Partnership decision:

In transactions that are designed to yield deferred rather than immediate returns, present value adjustments are, as the courts have recognized, an appropriate means of assessing the transaction's actual and anticipated economic effects.

We find no basis in the law for precluding a tax court's reliance on a present value adjustment where such an adjustment, under the surrounding circumstances, will serve as an accurate gauge of the reasonably expected economic consequences of the transaction.

In light of this decision, the courts are apparently willing to consider application of the discounted value approach, at least when doing so does not distort economic reality.

In conclusion, a transaction that is unprofitable before considering any of its tax benefits, whether or not a discounted value approach is used, will generally be determined to lack economic substance.

\section{Economic Risk}

The amount of economic risk inherent in a transaction is a concept closely related to the transaction's profit potential. A transaction that does not expose the taxpayer to any economic risk-that has "zero prospect of gain or loss"

Id. (citations omitted).

${ }^{64}$ ACM P'ship v. Comm'r, 73 T.C.M. (CCH) 2189, 2219 (1997), affd in part, rev'd in part, 157 F.3d 231 (3d Cir. 1998), cert. denied, 526 U.S. 1017 (1999).

${ }^{65} A C M$ P'ship, 157 F.3d at 259 (citations omitted). For a further discussion of $A C M$ Partnership, see Steven M. Surdell, ACM Partnership-A New Test for Corporate Tax Shelters?, 75 TAX NOTES 1377 (1997); Jennifer D. Avitabile, Note, Corporate Tax Shelter Lacked Economic Substance: ACM Partnership v. Commissioner, 51 TAX LAW. 385 (1998).

${ }^{66}$ Yosha v. Comm'r, 861 F.2d 494, 501 (7th Cir. 1988). 
nomic substance. ${ }^{67}$

[T] he courts have applied the economic substance doctrine ... to disregard transactions which, although involving actual transactions disposing of property at a loss, had no net economic effect on the taxpayer's economic position, either because the taxpayer retained the opportunity to reacquire the property at the same price, or because the taxpayer offset the economic effect of the disposition by acquiring assets virtually identical to those relinquished. ${ }^{68}$

For example, in Fender $v$. United States, the Fifth Circuit disallowed deductions for a loss that the taxpayers incurred on a bond sale. ${ }^{69}$ The unrated bonds were sold at a substantial loss to a bank that was approximately forty-one percent owned by the taxpayers. ${ }^{70}$ Although increased interest rates had caused the bonds' market value to decrease since the taxpayers had purchased them, the issuer was financially sound and capable of fulfilling its obligations relating to the bonds. ${ }^{11}$ A little more than a month after the sale, and in a new tax year, the taxpayers repurchased the bonds for roughly the same price for which they had sold the bonds. ${ }^{72}$ In examining the transaction, the court considered "whether the taxpayers were exposed to a real risk of not being able to repurchase the bonds in a short period of time and thus of not being able to recover the apparent loss from the ... sale to the bank." ${ }^{73}$ The court determined that the taxpayers had sufficient control over the bank to ensure that the bonds would be resold to them. ${ }^{74}$ Furthermore, the unrated nature of the bonds limited their marketability greatly and would have made it difficult for the bank to sell them to anyone but the taxpayers. While the initial sale created a genuine loss, the loss was effectively canceled by the subsequent re-

5.7 See id. at $\mathbf{5 0 0}$ ("Straddles that involve no market risks are not economically substantial straddles and hedges; they are artifices created by accomplices in tax evasion, the brokers."); Heltzer v. Comm'r, 62 T.C.M. (CCH) 518, 529 (1991) ("Commodity trading lacks economic substance where it is virtually risk-free ...."); see also Sochin v. Comm'r, 843 F.2d 351, 356 (9th Cir. 1988) ("[N]o reasonable investor would surrender total control of his or her ability to profit or lose unless satisfied that the risk of loss had been greatly diminished or eliminated.").

ACM P'ship, 157 F.3d at 249 (citations omitted).

577 F.2d 934, 938 (5th Cir. 1978).

Id. at $935-36$.

71 Id. at 936 .

I2. at $935-36$.

${ }^{73}$ Id. at 936 .

${ }^{74}$ Id. at 937 . 
purchase. The net nontax cash effect of the transactions was zero dollars. $^{75}$

\section{Other Factors}

In certain cases, particularly those involving sale-and-leaseback transactions, the courts have considered several other factors in determining whether a transaction exhibited economic substance. Some of these factors include: (1) the presence or absence of arm'slength price negotiations; (2) the relationship between the sales price and the fair market value; (3) the structure of the financing; (4) the degree of adherence to contractual terms; and (5) the reasonableness of income and residual value projections. ${ }^{76}$ For example, the taxpayers in Rose v. Commissioner ${ }^{77}$ purchased art masters ${ }^{78}$ that, according to the seller's marketing materials, provided certain tax advantages:

[A] purchaser is entitled to a $10 \%$ investment tax credit and accelerated depreciation deductions based on the entire purchase price of the art master. A purchaser who properly elects the accrual method of accounting for his trade or business of exploiting the art master is also entitled to currently accrue interest deductions on his notes, including the partial recourse note, and a cash basis taxpayer is entitled to a deduction for interest when actually paid. The investment credit available to the purchaser of an art master is not affected by the "at risk" limitation contained in the Code; however, losses incurred in the venture are subject to that limitation. A cash payment made by a purchaser, and all notes as to which the purchaser is personally liable, including the recourse portion of the partial recourse note, qualify as amounts at risk. Accordingly, purchasers of art masters will be allowed to deduct losses up to the total

${ }^{75}$ See id. at 936 ("Although the [taxpayers] appeared to sustain a significant loss by transferring the bonds to the bank..., the ability to repurchase these bonds meant that the [taxpayers] would eventually be paid their original investment in the bonds and would suffer no real loss from the sale.").

${ }^{76}$ See Frank Lyon Co. v. United States, 435 U.S. 561, 582-83 (1978) (listing a number of factors that the Court felt were meaningful in determining the "substance and economic realities of the transaction"); Bealor v. Comm'r, 72 T.C.M. (CCH) 730, 766 (1996) (same); Arrowhead Mountain Getaway, Ltd. v. Comm'r, 69 T.C.M. (CCH) 1805, 1817 (1995) (same), aff'd mem., 119 F.3d 5 (9th Cir. 1997); Levy v. Comm'r, 91 T.C. 838,856 (1988) (same); Rose v. Comm'r, 88 T.C. 386, 410-11 (1987) (same), affd, 868 F.2d 851 (6th Cir. 1989).

88 T.C. 386 (1987).

${ }^{78}$ An art master consisted of "silkscreen mylars, lithographic plates and mylars, or photoscreen negatives of an original work of art, together with related copyrights," which permitted the purchaser to produce products such as posters, greeting cards, and ceramics bearing the image of the original work of art. Id. at 390. 
of those amounts.

The taxpayers made no effort to inquire about the masters' true value, did not negotiate with the seller, and paid over $\$ 500,000$ for each master even though, at the time, the fair market values of the masters were negligible. ${ }^{80}$ Furthermore, the taxpayers financed their purchases with partial recourse notes, with the recourse portion approximately equal in value to the tax deductions the taxpayers anticipated they would take during the first two years of their investment. ${ }^{81}$ The nonrecourse portion of the debt was judged by the court as unlikely to be repaid because insufficient revenue would be generated by the investment. ${ }^{82}$ Based on these findings, the court held that the transaction lacked economic substance. ${ }^{83}$

In contrast to Rose is the case of Levy $v$. Commissioner, in which the taxpayers engaged in a purchase-and-leaseback of computer equipment $^{84}$ Relying on the same factors considered in Rose, ${ }^{85}$ the court held that the transactions possessed economic substance. ${ }^{86}$ The court determined that the purchase price paid by the taxpayers was reasonable and "resulted from arm's-length price negotiations" between unrelated parties. ${ }^{87}$ In addition, cash and recourse debt obligations with commercially reasonable interest rates financed the purchase. Finally, all payments required under the various promissory notes and lease agreements were made, and the court determined that all parties to the transaction intended to enforce the promissory notes and lease agreements according to their terms.

\section{Summary}

In its simplest terms, the economic substance doctrine examines the nontax economic benefits of a transaction. If the transaction is reasonably expected to be profitable, exposes the taxpayer to economic risk, or consists of other factors such as arm's-length price negotiations, then it is said to possess economic substance. Conversely, if

"Id. at $390-91$.

"Id. at 415-18.

Id. at $419-20$.

in Id. at 420 .

is Id. at 405 .

*4 91 T.C. 838,840 (1988).

See supra note 76 and accompanying text (listing factors used to determine the economic substance of sale-and-leaseback transactions).

Lery, 91 T.C. at 853-59.

${ }^{\mathrm{N}}$ Id. at 859 . 
the transaction lacks these traits, it is deemed to be without economic substance.

\section{B. Business Purpose Doctrine}

The business purpose doctrine is a subjective inquiry concerned with a taxpayer's motives for entering a transaction. ${ }^{88}$ The courts have set forth different formulations of the subjective test. ${ }^{89}$ The common theme of these expressions, however, is an inquiry into whether the transaction had a business purpose other than obtaining tax benefits.

The business purpose doctrine originated in Gregory $v$. Helvering. ${ }^{90}$ Mrs. Gregory was the sole stockholder of United Mortgage, which owned one thousand shares of stock in Monitor Securities ("Monitor")."

For the sole purpose of procuring a transfer of these shares to herself in order to sell them for her individual profit, and, at the same time, diminish the amount of income tax which would result from a direct transfer by way of dividend, she sought to bring about a "reorganization" under [the federal tax laws]. ${ }^{92}$

United Mortgage transferred the Monitor stock to Averill, a newly formed corporation. ${ }^{93}$ Three days later, Averill was dissolved and liquidated by the transfer of the Monitor stock to Mrs. Gregory, who immediately sold it. ${ }^{94}$ The Court held that the formation of Averill, the transfer of Monitor stock to it, and its subsequent liquidation, was an "operation having no business or corporate purpose." Averill existed solely to serve as a conduit to transfer Monitor shares to Mrs.

${ }^{88}$ Packard v. Comm'r, 85 T.C. 397, 417 (1985).

${ }^{89}$ See, e.g., ACM P'ship v. Comm'r, 157 F.3d 231, 253 (3d Cir. 1998) (asking whether the transaction was intended to serve any "useful non-tax purpose"), cert. denied, 526 U.S. 1017 (1999); Rice's Toyota World, Inc. v. Comm'r, 752 F.2d 89, 91 (4th Cir. 1985) (questioning whether "the taxpayer was motivated by no business purpose other than obtaining tax benefits in entering in the transaction"); see also Yosha v. Comm'r, 861 F.2d 494, 501-02 (7th Gir. 1988) ('Judges can't peer into people's minds or 'weigh' motives.... Rather, the usual approach is to focus the analysis on whether any non-tax goals or functions were or plausibly could have been served by the action.").

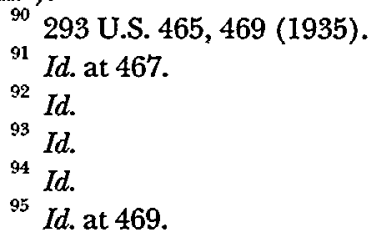


Gregory, so that she could avoid some taxes, after which point Averill "immediately was put to death. $"$ "

In contrast, in Moline Properties, Inc. v. Commissioner, the corporate taxpayer sought "to have the gain on sales of its real property treated as the gain of its sole stockholder and its corporate existence ignored as merely fictitious." ${ }^{\prime 97}$ The corporate taxpayer had originally been created for the stockholder's benefit, had existed for several years prior to the transaction at issue, and had engaged in business transactions both before and after the one at issue. ${ }^{98}$ The Supreme Court stated that in like cases, where the stockholder "adopt[s] the corporate form for purposes of his own[, t] he choice of the advantages of incorporation to do business ... require[s] the acceptance of the tax disadvantages." Furthermore, "in matters relating to the revenue, the corporate form may be disregarded where it is a sham or unreal," although it must be respected when there is a business purpose for the form that "is the equivalent of business activity or is followed by the carrying on of business by the corporation."100

A court's analysis of a taxpayer's alleged business purpose will often focus on whether the taxpayer "approached the decision to enter into [the] transaction in a businesslike manner." ${ }^{101}$ Numerous factors may be considered in making this determination. Some of the factors are: (1) the taxpayer's normal behavior when entering into a transaction for profit; (2) the taxpayer's principal line of business and whether it had previously been involved in transactions of the type at issue; (3) the extensiveness of the taxpayer's investigation into the merits of the transaction; (4) whether cash flow analyses were prepared that included the components of the transaction crucial to it earning a profit; (5) whether the significance of, and the risks associated with, these components were discussed; (6) whether an investigation was conducted to determine the business reputation and financial status of the other parties to the transaction; and (7) the extent to which the taxpayer focused on the tax benefits of the transaction in discussions with its advisors. ${ }^{102}$

Id. at 470 .

17319 U.S. 436,436 (1943).

Id. at $439-40$.

Ind at 439 .

I'*1 Id. (citations omitted).

'in' Levy v. Comm'r, 91 T.C. 838, 855 (1988).

"'See Casebeer v. Comm'r, 909 F.2d 1360, 1364 (9th Cir. 1990) (listing several factors that might be considered in "evaluating the taxpayers' business purpose"); Levy, 91 T.C. at 855-56 (same); Rice's Toyota World, Inc. v. Comm'r, 81 T.C. 184, 202 (1983) 
A review of the cases reveals that taxpayers have asserted a wide variety of business purposes. For example, one case involved a claim by a taxpayer that its business purpose for affiliating with a holding company was its fear of being held liable for one of the holding company's obligations and its concern over the adverse effect that a lawsuit would have on its credit standing. ${ }^{103}$ The court ultimately rejected the taxpayer's argument because it determined that the fear was groundless and "[a]ction motivated by a groundless fear cannot be considered motivated by a business purpose." ${ }^{104}$ Other examples of possible business purposes are diversification ${ }^{105}$ and financing requirements. $^{106}$

Perhaps the most common business purpose asserted, however, simply involves an inquiry into whether the taxpayer was profitmotivated. ${ }^{107}$ In Goldstein v. Commissioner, the taxpayer, after winning the Irish Sweepstakes, borrowed a large amount of money at an interest rate of $4 \%{ }^{108}$ The taxpayer used the borrowed funds to purchase Treasury notes that paid annual interest of $1.5 \%$ or less, and pledged the notes as collateral for the bank loans. ${ }^{109}$ The taxpayer then prepaid a significant amount of interest on the loans, hoping to claim an interest deduction that would shelter much of her Sweepstakes winnings from taxation. ${ }^{110}$ After reviewing the transaction, the court disal-

(same), aff'd in part, rev'd in part, 752 F.2d 89 (4th Cir. 1985).

${ }^{103}$ See David's Specialty Shops, Inc. v. Johnson, 131 F. Supp. 458, 460 (S.D.N.X. 1955) (presenting the taxpayer's alleged business purpose). From a tax perspective, the advantage of the attempted affiliation was that, if successful, it would have permitted the taxpayer to file a consolidated return with the holding company, thereby enabling the taxpayer to offset the holding company's net loss (which otherwise would have gone unused) against the taxpayer's net income. This would have reduced both the consolidated taxable income and the resulting tax liability. See id. at 459 (discussing the tax effects of consolidation).

${ }^{104} I d$. at 461.

${ }^{105}$ See Levy, 91 T.C. at 855 (concluding that the taxpayers "entered into the transaction in issue for sound business reasons"-to diversify their business investments).

${ }^{106}$ See Frank Lyon Co. v. United States, 435 U.S. 561,582 (1978) (noting that there were financing requirements imposed by state and federal regulators that caused the taxpayer to enter into the transaction).

${ }^{107}$ See, e.g., Rice's Toyota World, Inc. v. Comm'r, 752 F.2d 89, 92-94 (4th Cir. 1985) (reviewing the evidence to determine whether the taxpayer participated in the transaction to make a profit); Goldstein v. Comm'r, 364 F.2d 734, 739 (2d Cir. 1966) (examining the taxpayer's claim that she engaged in the transaction expecting to realize an economic gain from appreciation of the purchased property that would more than offset the unfavorable interest rate differential she incurred to purchase the property).

${ }^{108} 364$ F.2d at 736.

${ }^{109} I d$. at 736.

${ }^{110}$ Id. at $736-37$. 
lowed the deduction because it did not have a business purpose. ${ }^{111}$ The evidence, consisting of computations made by the taxpayer's advisor at the time she entered into the transactions, directly contradicted the taxpayer's claim that she anticipated significant market appreciation of the Treasury notes. ${ }^{112}$ The court stated that "a good example of [a] purposeless activity is the borrowing of funds at $4 \%$ in order to purchase property that returns less than $2 \%$ and holds out no prospect of appreciation sufficient to counter the unfavorable interest rate differential."113

\section{ANALYSIS OF THE TAX COURT'S OPINION IN COMPAQ}

The Tax Court's opinion in Compaq ${ }^{114}$ closely follows the traditional sham transaction analysis-examining both economic substance and business purpose-presented in Part II. ${ }^{115}$ Of particular emphasis in the opinion is the lack of any pretax profit potential in the Compaq transaction. ${ }^{116}$ The court states that the Commissioner "persuasively demonstrates that [Compaq] would incur a prearranged economic loss from the transaction" if tax benefits are not considered. $^{117} \mathrm{~A}$ cash flow analysis presented by the Commissioner, and adopted by the court, shows that the transaction resulted in a pretax net economic loss of $\$ 1,486,755$. $^{118}$

"III. at 737 .

${ }^{112}$ Id. at 739 .

${ }^{113}$ Id. at 742; see also Yosha v. Comm'r, 861 F.2d 494, 498 (7th Cir. 1988) ("[D]eliberately to incur an expense greater than the expected gain ... is the antithesis of profit-motivated behavior...."); Sheldon v. Comm'r, 94 T.C. 738, 763 (1990) ("Tax benefits could be the only purpose behind borrowing money at 10.88-percent interest in order to earn 10.42-percent interest.").

${ }^{114}$ Compaq Computer Corp. v. Comm'r, 113 T.C. 214 (1999).

${ }^{115}$ See supra Part II (examining the sham transaction doctrine as developed by the courts).

${ }^{116}$ See supra Part II.A.1.a (explaining that a transaction that possesses pretax profit potential has economic substance and is therefore not a sham transaction).

${ }^{117}$ Compaq, 113 T.C. at 222.

${ }^{118}$ Cash-flow from ADR transaction:

ADR purchase trades

ADR sale trades

$(\$ 887,577,129)$

$868,412,129$

Net cash from ADR transaction

Cash-flow from dividend:

Gross dividend

$22,545,800$

Netherlands withholding tax

$(3,381,870)$ 
Compaq, aware of the need to show that the ADR transaction possessed profit potential, presented its own analysis that attempted to show that the transaction resulted in a pretax profit of $\$ 1,895,115$. $^{119}$ The only difference between the Commissioner's calculation and Compaq's is that Compaq excluded the $\$ 3,381,870$ representing the Netherlands withholding tax paid on the Royal Dutch dividend. ${ }^{120}$ In essence, Compaq ignored a cost of the transaction-the Netherlands withholding tax-in calculating the transaction's pretax profit because Compaq would be able to recover that amount through the foreign tax credit. Thus, the withholding tax did not represent a true cost. ${ }^{121}$ The foreign tax credit, however, cannot be considered in determining whether a transaction had any profit potential independent of tax savings because it is a tax savings. ${ }^{122}$ As demonstrated by the Commis-

Net cash from dividend

$19,163,930$

Offsetting cash-flow residual

Cash-flow from transaction costs:

$(1,070)$

Commissions

Less adjustment

SEC fees

Margin writeoff

Interest

Net cash from transaction costs

Net economic loss

$(1,485,685)$

$(1,000,000)$

1,071

$(28,947)$

37

$(457,846)$

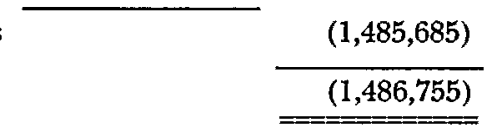

Id. at 223.

119 ADR transaction:

ADR purchase trades

ADR sale trades

$(\$ 887,577,129)$
$868,412,129$

Net cash from ADR transaction

Royal Dutch dividend

$(\$ 19,165,000)$

$22,545,800$

Transaction costs

$(1,485,685)$

Pretax profit

$\$ 1,895,115$

Id. at 221.

${ }^{120}$ See id. at 222 ("While asserting that it made a 'real' payment to the Netherlands in the form of the ... withheld tax, [Compaq] contends that that withholding tax should be disregarded in determining...the economic substance of the transaction.").

121 See id. at 221-22 (explaining Compaq's calculation of the pretax profit on the ADR transaction).

${ }^{122}$ See supra note 43 and accompanying text (stating that the economic substance 
sioner's analysis, the tax reporting approach used by Compaq to show a pretax profit-reporting the gross amount of the dividend even though only the net amount was received-could produce an economic gain only when the foreign tax credit was claimed. ${ }^{123}$

The court went on to find that Compaq did not face any real market risks by engaging in the transaction. ${ }^{124}$ The twenty-three cross trades occurred in about an hour, with each purchase and resale occurring almost simultaneously, at prices predetermined by TwentyFirst, the investment firm handling Compaq's transactions. As a result, there was "virtually no risk of price fluctuation." ${ }^{125}$ Furthermore, the use of special settlement terms and the large size of each trade minimized the risk of third parties breaking up the cross trades. Finally, there was "no risk of other traders breaking up the trades" because they occurred at the market price. ${ }^{126}$

The Tax Court also analyzed the transaction under the business purpose doctrine. ${ }^{127}$ The court rather quickly dismissed Compaq's argument that it entered the transaction intending to make a short-term profit. ${ }^{128}$ As was already discussed, the Commissioner demonstrated that the transaction could not possibly result in a pretax profit ${ }^{129}$ The court also noted that the transaction was marketed to Compaq as a way to shelter a portion of a previously recognized capital gain and that Compaq engaged in the multimillion dollar transaction based on little more than a one-hour meeting with Twenty-First. ${ }^{130}$ The court's final statement on this point is that Compaq's "evaluation of the proposed transaction was less than businesslike."

doctrine is concerned with the nontax benefits, if any, of a transaction).

${ }^{123}$ See Compaq, 113 T.C. at 223 (calculating a net economic loss, without considering the foreign tax credit, of $\$ 1,486,755$ as a result of the $A D R$ transaction).

${ }^{124}$ See supra Part II.A.2 (explaining that the lack of economic risk in a transaction is an indicator of a sham transaction).

${ }_{125}$ Compaq, 113 T.C. at 224.

I26. $I$.

${ }^{127}$ See supra notes $40-42$ and accompanying text (noting that the courts often examine a transaction under both the economic substance and business purpose doctrines before determining if it is an economic sham, because the failure to satisfy one of the tests does not constitute conclusive evidence of an economic sham).

See supra notes 107-13 and accompanying text (discussing profit motive as a basis to establish a valid business purpose).

1.4 See supra note 118 and accompanying text (calculating a net economic loss of $\$ 1,486,755$ from the transaction).

1*i See supra notes 101-02 and accompanying text (identifying several factors the courts will look at in analyzing a taxpayer's alleged business purpose).

${ }^{1 \times 1}$ Compaq, 113 T.C. at 224. 
The final portion of the opinion upholds the assessment of an accuracy-related penalty ${ }^{132}$ against Compaq on the basis that Compaq was negligent in taking the tax return position it did with respect to the ADR transaction. ${ }^{\mathrm{I} 3}$ Compaq argued that a negligence penalty could not be assessed "because the return position was reasonable, ${ }^{[13 i]}$ application of the economic substance doctrine to the ADR transaction is 'inherently imprecise', and application of the economic substance doctrine to disregard a foreign tax credit raises an issue of first impression." ${ }^{195}$ The court, however, found Compaq's arguments to be unpersuasive because the Compaq employees involved in the transaction "were sophisticated professionals with investment experience and should have been alerted to the questionable economic nature of the ADR transaction. They, however, failed to take even the most rudimentary steps to investigate the bona fide economic aspects of the ADR transaction." ${ }^{136}$ Furthermore, anyone with even a general familiarity with the sham transaction doctrine could have identified the $\mathrm{ADR}$ transaction as potentially abusive and deserving of a more thorough review than a one-hour meeting with the transaction's promoter and a perusal of a spreadsheet provided by the promoter.

\section{CRitique of Proposals to Combat Corporate TaX Shelters}

Transactions like the one in Compaq Computer Corp. v. Commissioner have prompted several groups to suggest steps that should be taken to protect the integrity of the Internal Revenue Code ("Code"). ${ }^{137}$ Not only do abusive corporate tax shelters wrongfully deprive the federal

${ }^{132}$ See I.R.C. $\$ \$ 6662(a)$, (b) (1) (1994) (providing for a penalty equal to twenty percent of the amount of any underpayment of tax attributable to negligence).

${ }^{133}$ See I.R.C. $\$ 6662$ (c) (1994) (defining negligence as "any failure to make a reasonable attempt to comply with the provisions of [the Internal Revenue Code]").

${ }^{134}$ See I.R.C. $\$ 6664$ (c)(1) (1994) ("No [accuracy-related] penalty shall be imposed ... with respect to any portion of an underpayment if it is shown that there was a reasonable cause for such portion and the taxpayer acted in good faith with respect to such portion.").

${ }^{135}$ Compaq, 113 T.C. at 227.

${ }^{136} I d$.

${ }^{137}$ See, e.g., Abusive Tax Shelter Shutdown Act of 1999, H.R. 2255, 106th Cong. (attempting to eliminate abusive corporate tax shelters); I.R.S. Announcement 2000-12, 2000-12 I.R.B. 835 (introducing temporary and proposed regulations specifically directed at corporate tax shelters); JCT PROPOSAL, supra note 5 (making suggestions to reduce corporate tax shelter activity); TREASURY WHITE PAPER, supra note 3 (providing background on the corporate tax shelter problem and making proposals to solve it); Tax Section, New York State Bar Ass'n, supra note 6 (proposing ways to combat the corporate tax shelter problem). 
treasury of revenues, ${ }^{138}$ but the knowledge that some taxpayers are getting away with it encourages others to pursue similar transactions. ${ }^{139}$

The main proposals designed to curb corporate tax shelters are: (1) increasing disclosure of tax advantaged transactions; (2) increasing penalties for improper tax shelters; (3) creating consequences for promoters, advisors, and tax-indifferent parties involved in the transactions; and (4) codifying existing judicial anti-tax-avoidance doctrines. The specific means by which each of these proposals would be implemented depends on the group making the proposal. What is important at this point in the debate, however, is not to identify exactly how the various proposals should be implemented, but which of the proposals deserve the most attention.

Although Treasury has issued temporary and proposed regulations on the corporate tax shelter problem, an examination of the broader issues is still important because the corporate tax shelter debate continues in Congress, Treasury, and the profession. Furthermore, the temporary and proposed regulations only address the issue of greater corporate tax shelter disclosure, and there is still the possibility that the regulations will undergo significant changes before they become final. ${ }^{140}$ Nevertheless, a more specific discussion of the regulations and their requirements is included in this Comment because they are currently the most authoritative pronouncements on the issue. It should be noted that several groups have already written lengthy comments to the Commissioner on the temporary and proposed regulations, and this Comment makes no attempt to undertake a similarly in-depth and narrow critique. ${ }^{141}$

${ }^{13 *}$ See supra note 7 and accompanying text (stating that corporate tax shelters annually reduce federal tax revenues by at least ten billion dollars).

After all, if others are able to reduce their taxes, thereby keeping more money for themselves, why shouldn't you? See WALl STREET (20th Century Fox 1987) ("[G]reed, for lack of a better word, is good. Greed is right. Greed works."). But see Mark 10:25 ("It is easier for a camel to go through the eye of a needle than for a rich man to enter the kingdom of God.").

An analogous situation is presented in the question of legal ethics, in which those lawyers that "practice closest to the line without crossing seem to gain an advantage. Goaded by the market, conscientious lawyers ask whether they do their clients a disservice if they don't exploit every opening." LINCOLN CAPLAN, SKADDEN 138 (1993).

${ }^{1 *}$ See T.D. $8875,2000-11$ I.R.B. 761 (requiring corporate tax shelter promoters to maintain customer lists); T.D. 8876, 2000-11 I.R.B. 753 (requiring corporate tax shelter registration); T.D. 8877, 2000-11 I.R.B. 747 (requiring taxpayer disclosure of participation in corporate tax shelters).

${ }^{141}$ See, e.g., Letter from Douglas J. Antonio, Chair, Federal Taxation Committee, Chicago Bar Association, to the Internal Revenue Service (May 17, 2000), in 2000 TAX NOTES TODAY 102-27, WL 2000 TNT 102-27 [hereinafter Chicago Bar Association Let- 


\section{A. Increase Disclosure Requirements for Tax Shelters}

Increased disclosure of corporate tax shelters has the greatest potential value of the proposals, and Treasury's temporary and proposed regulations are the most significant attempt to implement any of the proposals. Perhaps the greatest problem currently facing the Commissioner is finding potentially abusive transactions hidden in the millions of returns that are filed each year. ${ }^{142}$ Requiring companies to clearly identify such transactions, as contemplated by the temporary and proposed regulations, should allow the Commissioner to concentrate his resources on attacking, rather than vainly searching for, abusive transactions. If the temporary and proposed regulations are successful in forcing companies to disclose all of their "suspect" transactions, ${ }^{143}$ the companies will no longer be able to rely on win-

ter] (providing comments on the temporary and proposed regulations); Letter from David A. Lifson, Chair, Tax Executive Committee, American Institute of Certified Public Accountants, to Charles O. Rossotti, Commissioner, Internal Revenue Service (May 31, 2000), in 2000 TAX NOTES TODAY 106-13, WL 2000 TNT 106-13 [hereinafter AICPA letter] (same); Letter from Charles W. Shewbridge, III, International President, Tax Executive Institute, Inc., to the Internal Revenue Service (June 5, 2000), in 2000 TAX NOTES TODAY 118-75, WL 2000 TNT 118-75 [hereinafter TEI letter] (same).

${ }^{142}$ See George Hager, Treasury Targets Shelters Again, WASH. POST, July 2, 1999, at E3 ("To shoot down tax shelters... the IRS must first find them, and that has proven to be extremely difficult. Some estimates indicate that the government ferrets out or stumbles on barely one out of 10 shelters, while the rest stay hidden in tax returns that might never get audited."); James Lardner, Corporations Sing. Gimme Tax Shelter and the Treasury Department Gets the Blues, U.S. NEWS \& WORLD REP., Apr. 5, 1999, at 49, 49 ("Today's shelters ... are artfully concealed in the minutiae of a tax return."); Summers, supra note 3. ("What we see, we can act upon. What we cannot see, by definition, we cannot act upon. But what we fear is that visible corporate tax shelters are only the tip of the iceberg.").

${ }^{143}$ How exactly to define a corporate tax shelter is an ongoing debate to which there is no easy answer. "Because corporate tax shelters take many different forms and utilize many different structures, they are difficult to define with a single formulation." TREASURY WHITE PAPER, supra note 3, at v. If there were a perfect definition of a corporate tax shelter, the problem of corporate tax shelters would disappear. Congress would merely need to pass a law stating that corporate tax shelters (as defined by the perfect definition) are prohibited. Little related to taxation, however, is that simple. Although a number of definitions have been proposed, see John J. Tigue, Public Enemy No. 1-Comporate Tax Shelters, 222 N.Y. L.J. 3 (1999), the best appears to be a list of characteristics, which is more a description, as opposed to a definition, of corporate tax shelters. The characteristics of such a transaction include: (1) lack of economic substance to the participating parties; (2) inconsistent financial accounting and tax treatments; (3) involvement of tax-indifferent parties; (4) marketing activity; (5) confidentiality requirements; (6) contingent or refundable fees and rescission or insurance arrangements; and (7) high transaction costs. See TREASURY WHITE PAPER, supra note 3, at 11-25 (listing characteristics of corporate tax shelters). A more humorous description, but no less accurate, is: "'a deal done by very smart people that, absent tax considerations, would be very stupid." Id. at 12 (quoting Professor Michael Graetz). 
ning the corporate tax shelter "lottery" by investing in questionable tax shelter transactions knowing that the Commissioner is unlikely ever to question them, and that if he does, it will only be after the passage of many years. ${ }^{144}$

\section{Temporary and Proposed Regulations}

\section{a. Under $\$ 6111$}

The disclosure statute, $\$ 6111$ of the Code, ${ }^{145}$ was originally enacted in 1984, and captured within its tax shelter definition most of the transactions then marketed to individuals. ${ }^{146}$ The statute was amended in 1997 to include the new corporate tax shelters within the statute's definition of transactions that must be disclosed. ${ }^{147}$ The amended portion of the statute, however, became effective only recently when Treasury issued temporary and proposed regulations un$\operatorname{der} \$ 6111$. $^{148}$

Ultimately, in its temporary and proposed regulations, Treasury chose to rely on a list of factors. See infra notes 158-65 and accompanying text (defining "reportable transaction").

144 See Howard Gleckman \& Lorraine Woellert, Kiss that Tax Shelter Goodbye?, Bus. WK. Nov. 15, 1999, at 50, 50 ("A lot of the [tax shelters] are premised on the fact that they won't be detected. Once they are, they just don't wash." (quoting John E. Chapoton, a partner at Vinson \& Elkins)); Lardner, supra note 142, at 49 ("One of the hallmarks of the modern tax shelter ... is the assumption by all parties involved that it will be shut down if staffers at the Treasury Department or Congress happen to discover it.").

143 See I.R.C. \$6111(a) (1) (1994) ("Any tax shelter organizer shall register the tax shelter with the Secretary... not later than the day on which the first offering for sale of interests in such tax shelter occurs.").

${ }^{146}$ See Joseph Bankman, The New Market in Corporate Tax Shelters, 83 TAX NOTES 1775,1788 (1999) ("As originally enacted, its definition of tax shelter captured most of the characteristics of the shelters marked [sic] to high-income individuals; the definition of tax shelter did not obviously encompass the new corporate tax shelters.").

${ }^{147}$ See id. (explaining that the original disclosure statute had to be amended to reach corporate tax shelters, which were not a problem when the statute was first enacted).

148 See Taxpayer Relief Act of 1997, Pub. L. No. 105-34, 111 Stat. 788, 928 ("[T] amendments made by this section shall apply to any tax shelter ... interests in which are offered to potential participants after the Secretary of the Treasury prescribes guidance with respect to meeting requirements added by such amendments."); T.D. $8876,2000-11$ I.R.B. 753, 753 (requiring the registration of corporate tax shelters). Treasury's delay in exercising its authority to trigger the registration requirements was the result of a desire to wait until a final determination was made by all relevant parties as to how to deal with corporate tax shelters. See Springsteel, supra note 7 ("[T] he reason the IRS delayed guidance on the [disclosure requirements] was that the agency wanted to make sure its application would be consistent with the broader approach, which has been in the works since [the fall of 1998]."). 
The effectiveness of the disclosure required by the temporary and proposed regulations issued under $\S 6111$ should be judged by whether the scope is broad enough to capture the vast majority of corporate tax shelters, but not so broad that the Commissioner is overwhelmed by disclosures of legitimate transactions. ${ }^{149}$ Whether the current statute meets these standards is unknown since it is only since late February 2000 that any attempt has been made to utilize it. ${ }^{150} \mathrm{~A}$ possible clue is provided, however, by the 1997 amendment, which defines a tax shelter that would need to be disclosed as a transaction subject to certain confidentiality agreements. ${ }^{151}$ The reason for this language is that, historically, corporate tax shelter promoters required prospective purchasers of their "products" to sign confidentiality agreements as a means of protecting the value of the product. ${ }^{152} \mathrm{Al}-$ though such agreements are still used, promoters are increasingly willing to market products without them. ${ }^{158}$

It is highly likely that confidentiality agreements would disappear completely from the tax shelter market-and be replaced by a substitute, such as a "gentleman's agreement"-if it meant that the promoter would not need to disclose the tax shelter to the Commissioner. The government apparently believes that this will happen, since its estimate of the impact of the new $\S 6111$ temporary and proposed regulations is that only four corporate tax shelters will be registered. ${ }^{154}$ It is

149 See Bankman, supra note 146, at 1790 ("While disclosure of the hundred or so tax shelters extant at any moment might be extremely helpful to the IRS, receipt of all materials relating to all or most agreements for which accounting firms and investment banks receive fees would rob disclosure of any real utility.").

${ }^{150}$ For all practical purposes, it was not until late August 2000 that a real attempt to require disclosure under $\$ 6111$ was made. See T.D. 8876, 2000-11 I.R.B. 753, 753 (providing that no registration need be filed until August 26, 2000, 180 days after the effective date of the regulation).

${ }^{151}$ See I.R.C. $\$ 6111$ (d) (1) (Supp. IV 1998) (defining tax shelter, for purposes of requiring disclosure, to include certain confidential arrangements).

${ }^{152}$ See Bankman, supra note 146 , at 1781 (“[A] promoter has no generally enforceable intellectual property rights in the idea around which the tax shelter is built.... Promoters attempt to limit ... expropriation [of their ideas] by requiring confidentiality agreements from prospective purchasers and their advisors.").

${ }^{153}$ See id. ("Many promoters ... rely on repeat business and long-standing relationships in lieu of [confidentiality] agreements."); Novack \& Saunders, supra note 7, at 208 (" $[\mathrm{P}]$ romoters have already taken evasive action. To avoid registration, they have stopped asking clients to sign 'confidentiality' agreements. Clients know that if they blab, they won't see the next hot deal.").

${ }^{154}$ See Sheryl Stratton, Disclosure Regs Overbroad and Burdensome, but Are They Effective?, 57 TAX ANALYSTS' DAILY TAX HIGHLIGHTS \& DOCUMENTS 2255, 2255 (2000) (“A May report... states that the government anticipates a whopping four corporate tax shelters would be registered as a result of the regs."). 
therefore unlikely that the $\$ 6111$ temporary and proposed regulations will have any effect (other than the disappearance of confidentiality agreements) on corporate tax shelter activity.

Treasury was limited by the language of $\S 6111$ in promulgating the temporary and proposed regulations under it and cannot be faulted for the limited effect of the regulations. Although Congress could amend $\S 6111$ to remove the confidentiality requirement, such action would be unnecessary in light of the other temporary and proposed regulations promulgated by Treasury, which, as discussed below, provide for adequate disclosure of corporate tax shelters.

\section{b. Under $\$ 6112$}

Treasury also issued temporary and proposed regulations under $\$ 6112$ that require "any person who organizes or sells any interest in a potentially abusive tax shelter [to] maintain a list identifying each person who was sold an interest in such shelter."155 The information on the list must be maintained for seven years, and it must be made available for inspection at the request of the Secretary of the Treasury.

To avoid the probably limited effect of the $\$ 6111$ temporary and proposed regulations, the $\$ 6112$ temporary and proposed regulations use a modified version of the $\S 6111$ confidential corporate tax shelter definition to define "potentially abusive tax shelter." Specifically, the regulations "include[] a transaction for which a significant purpose of the structure of the transaction is the avoidance or evasion of Federal income tax," but do not require confidentiality or $\$ 100,000$ in promoters' fees. ${ }^{156}$

The list maintenance requirement raises the cost of investing in a transaction that may eventually be found to be a corporate tax shelter because it allows the Commissioner to easily identify every investor in that corporate tax shelter once he has identified a single investor. Thus, even if a particular taxpayer initially escapes the Commissioner's scrutiny by winning the audit lottery, its victory is only illusory unless every other name on the list also wins the lottery. The resulting change in the cost/benefit calculation for taxpayers considering the purchase of a corporate tax shelter should reduce corporate tax shelter activity, since only those corporate tax shelters that offer the greatest benefits will be able to justify the higher cost. ${ }^{157}$

${ }^{155}$ T.D. $8875,2000-11$ I.R.B. $761,761$.

IJ" at 762 .

157 The simple example that follows illustrates the impact of the list maintenance 


\section{c. Under $\S 6011$}

The most important of the temporary and proposed corporate tax shelter regulations requires taxpayer disclosure of "reportable transactions" on their tax returns. ${ }^{158}$ The disclosure is accomplished by having the taxpayer attach a disclosure statement to its tax return for each year that its participation in the transaction affects its tax liability. ${ }^{159}$ In addition, the taxpayer must send a copy of its disclosure statement to the Commissioner in Washington, D.C. for the first year that the taxpayer discloses the transaction on its return. ${ }^{160}$

The term "reportable transaction" covers two broad categories of transactions. ${ }^{161}$ The first category includes transactions identical to, or substantially similar to, those identified by the Commissioner in published guidance as $\S 6011$-listed transactions that are expected to reduce the taxpayer's tax liability by more than $\$ 1$ million in any one year, or more than $\$ 2$ million for any combination of years. ${ }^{162}$ The second category includes transactions that contain at least two out of six listed characteristics and are expected to reduce the taxpayer's tax liability by more than $\$ 5$ million in any one year, or more than $\$ 10$ million for any combination of years. ${ }^{163}$ The six listed characteristics are: (1) the transaction was engaged in under conditions of confidentiality; (2) the taxpayer is contractually protected against the loss of part or all of the tax benefits of the transaction; (3) the party that

requirement on the odds that a particular taxpayer's involvement in an abusive corporate tax shelter will be discovered and the tax benefits disallowed. Assume that Romeo, Rosebud \& Radar is a corporate tax shelter promoter that sells a particular corporate tax shelter to five companies. Further assume that absent the list maintenance requirement each of the five companies faces only a ten percent risk that their purchase of the corporate tax shelter will be discovered and the tax benefits disallowed. In the absence of the list maintenance requirement, the discovery of Edick's involvement in the corporate tax shelter would have no impact on the odds that Lloyd's involvement would be discovered-Lloyd would still face only a ten percent risk of discovery and disallowance. With the list maintenance requirement, however, each of the five companies now faces a forty-one percent risk of discovery and disallowance: $1-(1-.1)^{5}$. See Interview with Thomas J. Brennan, Ph.D., in N.Y., N.Y. (July 29, 2000) (explaining the mathematical principles underlying the calculation of the list maintenance requirement's impact on the risk of discovery and disallowance). Comparing the different odds demonstrates that, in this example, the list maintenance requirement more than quadruples the risk of discovery and disallowance.

${ }^{158}$ T.D. 8877, 2000-11 I.R.B. 747, 747.

${ }^{159} I d$.

${ }^{160} I d$.

${ }^{161} \mathrm{Id}$.

${ }^{162} I d$. See I.R.S. Notice $2000-15,2000-12$ I.R.B. 826 , for the initial list of $\$ 6011$ reportable transactions.

${ }^{163}$ T.D. $8877,2000-11$ I.R.B. $747,747$. 
promoted, sold, or recommended the transaction to the taxpayer received, or is expected to receive, at least $\$ 100,000$ in fees; (4) the tax and book treatment of the transaction results in, or is expected to result in, at least a five million dollar difference in tax treatment; (5) the transaction involves the participation of a party in a different tax position than the taxpayer that allows the transaction to be structured in a way that is more favorable for the taxpayer; and (6) the expected characterization of the transaction for United States tax purposes differs from the expected characterization by any party to the transaction for purposes of taxation in another country. ${ }^{164}$ Several exceptions exist to prevent taxpayers from having to disclose transactions that have at least two of the six characteristics, but that are nevertheless unlikely to be corporate tax shelters. The exceptions include transactions identified by the Commissioner in published guidance as not requiring disclosure, transactions that the taxpayer has participated in "in the ordinary course of its business in a form consistent with customary commercial practice," and transactions for which there is no reasonable basis for the Commissioner to deny any significant portion of the expected tax benefits. ${ }^{165}$

Despite Treasury's best efforts to write the temporary and proposed regulations so that only significant corporate tax shelters will be disclosed, the regulations have been criticized as overly broad. ${ }^{166}$ It is asserted that the regulations generally capture every transaction a taxpayer engages in and do not contain adequate exceptions, thus requiring taxpayers to disclose more transactions than the Commissioner could ever investigate. Most of these criticisms seem to ignore (perhaps unsurprisingly given that many corporate tax shelters are based on a similarly myopic reading of the law) the clear intent of the regulations to primarily capture corporate tax shelters. For example, the exceptions for transactions that are entered into in the ordinary course of business and in a customary form are designed to eliminate from disclosure many of the everyday transactions that various groups misinterpreting the regulations fear will have to be disclosed.

Nevertheless, if taxpayers are advised by their tax counsel to disclose every transaction, then the temporary and proposed regulations

Iot Id.

165 Id.

${ }^{160}$ See, e.g., Chicago Bar Association Letter, supra note 141 (identifying concerns that the temporary and proposed regulations contain definitions that capture too many transactions not normally considered tax shelters); AICPA letter, supra note 141 (same); TEI letter, supra note 141 (same). 
will prove ineffective as the Commissioner will be left in virtually the same position as he is now, except with thicker returns. While this outcome is unlikely given the tremendous expenditure of resources taxpayers would have to make and the degree to which Treasury's intent would have to be misinterpreted, it would require Treasury to reconsider the temporary and proposed regulations. One solution might be to impose a penalty on taxpayers who make frivolous disclosures. Another possible solution, and the one urged by the tax professionals claiming that the regulations are overly broad, would be to narrow the definition of reportable transaction or to expand the exceptions. These are less attractive alternatives, however, as they would simply give the corporate tax shelter organizers and promoters more room in which to maneuver-the likely purpose behind their dire predictions.

With the temporary and proposed regulations now in place, it would be wise to "see how [they] actually work" before making changes. ${ }^{167}$ If they are as seriously flawed as the criticisms mentioned above would suggest, then taxpayers, Treasury, and the Commissioner will have plenty of evidence to support changes soon enough. On the other hand, all interested parties may discover, to the displeasure of some, that Treasury has struck a fatal blow against corporate tax shelters.

\section{Additional Disclosure Proposals}

Several of the proposals to increase disclosure suggest requiring a corporate official to sign the disclosure, attesting to its veracity and to the legitimacy of the transaction. ${ }^{168}$ "Certification would ... increase the significance of an aggressive transaction in the organization .... The combination of factual disclosure and involvement of a senior executive officer will get behavior modification,... which would be more effective than the threat of penalties, litigation, or audits." ${ }^{\text {"69 }}$ The idea is that once the company official becomes personally associated with the transaction, he will be more concerned about

${ }^{167}$ Ryan J. Donmoyer, Archer Rebuffs Treasury Call for Shelter Legislation, 2000 TAX NOTES TODAY 56-3, WL 2000 TNT 56-3 (quoting Congressman William Archer).

${ }^{168}$ See, e.g., Abusive Tax Shelter Shutdown Act of 1999, H.R. 2255, 106th Cong. (1999) (requiring a statement signed by a senior corporate officer attesting to the veracity of the facts and conclusions relied upon in reporting the disclosed transaction).

${ }^{169}$ Sheryl Stratton, Tax Shelter Approaches Debated, 2000 TAX NOTES TODAY 15-2, WL 2000 TNT 15-2. 
its merits and will refuse to participate in the most egregious schemes. ${ }^{100}$

Interestingly, Compaq sought to accomplish the same goal as this proposal, albeit through the use of a slightly different method. In its opinion, the Tax Court unveiled its newest weapon in the arsenal against corporate tax shelters: the "scarlet letter."171 The name of James J. Tempesta, an assistant treasurer at Compaq who was primarily responsible for Compaq's involvement in the ADR transaction, appears more than a dozen times in the Tax Court's opinion. ${ }^{172}$ The court even went so far as to discuss Tempesta's educational background in the opinion. ${ }^{173}$ It is hard to imagine how anyone with career ambitions would be indifferent about having his name appear numerous times within a court opinion adverse to his company, and in which a transaction for which he is responsible is declared a sham. ${ }^{174}$ Corporate employees responsible for recommending transactions for their companies to pursue may be more cautious if they cannot expect to hide behind the corporate cloak as unnamed, and unmentioned, actors when things go bad.

The Senate Finance Committee must also be thinking of the effec-

17" See Ian Springsteel, Trojan Horses, CHIEF EXECUTIVE, Oct. 1999, at 20, 20, available at $1999 \mathrm{WL} 14843176$ ("Once executive officers are on the line, they will insist that the real due diligence on these transactions get done, with the result that most will never be entered into' ...." (quoting Stefan F. Tucker, a partner at Tucker, Flyer LLP and chair of the ABA Section of Taxation)).

17 See NATHANIEL HAWTHORNE, THE SCARLET LETTER 43 (Scully Bradley et al. eds., W. W. Norton \& Co., $2 \mathrm{~d}$ ed. 1978) (1850) (describing the large red "A" that an adulterer was required to wear as punishment for her crime).

172 Compaq Computer Corp. v. Comm'r, 113 T.C. 214 (1999).

${ }^{173}$ See id. at 216 ("He received his undergraduate degree in philosophy and government from Georgetown University and his master's degree in finance and accounting from the University of Texas.").

${ }^{174}$ See Bankman, supra note 146, at 1784 ("Executives often bring up the possibility of public exposure in evaluating a prospective shelter ...."); Springsteel, supra note 170 , at 20 (noting that the first question every CEO should ask when considering whether to pursue a tax savings transaction is: "What do you believe would happen to the employee, community, and customer image of the company and its brand if the company were named as part of a tax avoidance scheme?"). But see Bankman, supra note 146, at 1784 (stating that the executive most responsible for Colgate-Palmolive's participation in the transaction at issue in ACM Parinership v. Commissioner, 157 F.3d 231 (3d Cir. 1998), cert. denied, 526 U.S. 1017 (1999), "got promoted, notwithstanding the seemingly unfavorable publicity and unfavorable outcome of the ensuing case"); $c f$. JOE DOMANICK, FAKING IT IN AMERICA: BARRY MINKOW AND THE GREAT ZZZZ BEST SCAM 280 (1989) (describing the dozens of job offers that Mark Morze received even as he awaited sentencing for his involvement with the financial and securities fraud at ZZZZ Best). On the other hand, maybe a certain thrill is derived from seeing one's own name in print. 
tiveness of the scarlet letter in controlling behavior. It has proposed that any company that pays more than one million dollars in corporate tax shelter related penalties in any year disclose that fact to shareholders. ${ }^{175}$ Most shareholders would likely find such a disclosure troubling since it means that the company has both lost the money it paid to participate in the corporate tax shelter, and unnecessarily paid an additional sum to the government. ${ }^{176}$ Out of concern for their professional survival, corporate executives generally want to avoid black marks, such as "investments" questionable enough to give rise to understatement penalties, that shareholders and the market could interpret as indicators that they are not running the company as efficiently as others could.

\section{B. Increase Penalties for Engaging in Abusive Tax Shelters}

As demonstrated in Compaq, the existing penalty system can, and will, be used against parties that engage in corporate tax shelters. ${ }^{137}$ The initial point to realize about any penalty system, however, is that it will only be as effective as the mechanism used to discover transactions that are subject to the penalty. Given the current difficulty the Commissioner has in discovering tax shelter transactions, ${ }^{178}$ increasing the understatement penalty will not, by itself, be effective. ${ }^{179}$ Under the current detection system, taxpayers simply do not face a great enough

${ }^{175}$ See Ryan J. Donmoyer \& Heidi Glenn, Finance Antishelter Draft' Boosts Penalties, Standards of Conduct, 2000 TAX NOTES TODAY 102-1, WL 2000 TNT 102-1 (stating that the Senate Finance Committee staff proposal would require corporations to disclose penalty payments).

${ }^{176}$ It is true that a shareholder might be pleased by the penalties as they indicate that the company is aggressively seeking to limit its tax liability, thereby leaving more money available for investment in ongoing operations or dividend payout. This view seems a bit overly optimistic, however, as it ignores the fact that shareholders can be certain about the costs that management has incurred-the penalties-but will always lack any particular knowledge about the benefits achieved-the tax savings that went undetected. Management cannot sensibly publicize the tax savings, since to do so would be to alert the Commissioner to the fact that he should take another look at the company and its tax returns.

${ }_{177}$ Compaq Computer Corp. v. Comm'r, 113 T.C. 214, 226-27 (1999); see infra notes 188-91 (describing the historical application of penalties in corporate tax shelter cases and the limited effort apparently necessary to avoid them).

${ }^{178}$ See supra notes $142-44$ and accompanying text (discussing the difficulty the Commissioner currently has in finding corporate tax shelter transactions).

${ }^{179}$ Several of the proposals, apparently recognizing this fact, would impose an increased penalty but allow for it to be reduced if the taxpayer makes certain disclosures. See infra note 204 and accompanying text (describing the proposed penalty revisions). 
risk of detection for any reasonable penalty to serve as an adequate deterrent. ${ }^{1 * 4}$

Although increased penalties may not deter taxpayers from engaging in tax shelters, there is a concern that they may deter taxpayers from engaging in legitimate transactions for fear of the possibility of being assessed a large penalty ${ }^{181}$ Such a concern is unfounded, however, as the current system uses a negligence $\operatorname{standard}^{182}$ and requires only that the taxpayer make a reasonable attempt to comply with the tax laws. ${ }^{183}$ Furthermore, the penalty does not apply to any portion of an understatement for which "there is or was substantial authority for such treatment ${ }^{\text {sił }}$ unless the understatement is attributable to a tax shelter, in which case the taxpayer must also show that he "reasonably believed that the tax treatment of such item by the taxpayer was more likely than not the proper treatment." ${ }^{, 185}$ Finally, "[n]o penalty shall be imposed... with respect to any portion of an underpayment if it is shown that there was a reasonable cause for such portion and that the taxpayer acted in good faith with respect to such portion.,1866 It was the inability of Compaq to meet even these minimum standards that led the court to assess a penalty in that case. ${ }^{187}$

IN" Greatly simplifying the cost/benefit factors a taxpayer would consider in determining whether to engage in a particular corporate tax shelter will make clear just how large a penalty would need to be. In the first example, Colleen \& Josh is considering a tax shelter that will save it $\$ 100$ if undetected, but that will be completely disallowed if discovered. Assume, however counterfactual it may be, that the transaction faces a $50 \%$ risk of detection. Only if the penalty rate is at least $100 \%$ will Colleen \& Josh choose not to engage in the transaction: $(\$ 100 * .50)<(\$ \mathrm{X} * .50)$. In the second example, Julien is considering the same transaction, but now the risk of detection is only $25 \%$. Under these conditions, the penalty rate would need to be at least $300 \%$ for Julien to pass on the transaction: $(\$ 100 * .75)<(\$ \mathrm{X} * .25)$. But see Kenneth J. Kies, $A$ Critical Look at the Administration's 'Corporate Tax Shelter' Proposals, 83 TAX NOTES 1463, 1476 (1999) ("[T]he accuracy-related penalty provides a powerful incentive for corporate tax executives to review closely and analyze both the structure and the implementation of any proposed business transaction that results in tax benefits, and to impose prudence on the decision-making process.").

'1*1 See Bankman, supra note 146 , at 1794 ("The complaint against the high penalty rate under the Treasury proposals is ... that the government would incorrectly apply the penalty provisions to non-shelter transactions, or that investors would fear such incorrect application.").

${ }^{1 \times 2}$ See I.R.C. $\$ 6662$ (b) (1) (1994) (stating that the accuracy-related penalty applies when the underpayment is attributable to negligence).

IN $\$$ See I.R.C. $\$ 6662$ (c) (1994) (defining negligence as "any failure to make a reasonable attempt to comply with the provisions of [the Internal Revenue Code]").

I*A I.R.C. $\$ 6662$ (d) (2) (B) (i) (1994).

is: I.R.C. $\$ 6662$ (d) (2) (C) (i) (II) (1994).

lixit I.R.C. $\$ 6664$ (c) (1) (1994).

${ }^{1 \times 7}$ See Compaq Computer Corp. v. Comm'r, 113 T.C. 214, 227 (1999) (stating that 
In fact, although nothing in the language of the existing understatement penalty specifically prevents its application in corporate tax shelter cases, it has only rarely been applied in such cases. The courts have ordinarily given a broad reading to the reasonable cause test whereby the taxpayer's possession of a more-likely-than-not opinion serves to establish that there was a reasonable basis for the transaction, thus avoiding imposition of a penalty. ${ }^{188}$ Given the large number of tax lawyers in the United States, and their differing interpretations of the tax laws, a taxpayer can generally obtain a more-likely-than-not opinion for any corporate tax shelter transaction. As a result, corporate tax shelter "[o]pinions are like pasties and G-strings. They attempt to obscure what is really going on but do not succeed."

In an effort to provide more consistency in tax opinions, particularly with respect to corporate tax shelter transactions, Treasury has proposed to revise Circular No. 230, which provides requirements for tax professionals that practice before the Internal Revenue Service. ${ }^{190}$ The current requirements were not designed with corporate tax shelter opinion writing in mind, and thus do not provide sufficient incentive for tax professionals to question the propriety of writing a suspect opinion. The presently available sanctions are suspension of an individual's ability to practice before the Internal Revenue Service, disbarment of an individual from practice before the Internal Revenue Service, and, in at least some cases, private reprimand. ${ }^{191}$ Groups have proposed that the sanctions be expanded to include "public censure," "the imposition of fines in amounts bearing a reasonable relationship to the practitioner misconduct,"193 and the "exten[sion of]

Compaq "offered no evidence that it satisfied the 'reasonable and ordinarily prudent person' standard or relied on the advice of its tax department or counsel").

${ }^{188}$ See David C. Garlock, A Tax Executive's Guide to Evaluating Tax-Oriented Transactions, at http://www.bna.com/tmweb/memo3.htm (last modified Oct. 27, 1998) (stating that to avoid an understatement penalty a corporation needs "to obtain a morelikely-than-not (or stronger) opinion from a reputable tax advisor unrelated to the promoter that is based on the actual facts of the transaction and that contains a reasonable discussion of the transaction's business purpose and economic substance").

${ }^{189}$ Lee A. Sheppard, Shelter Opinions: The Tax Equivalent of Pasties, 87 TAX Notes $17,20(2000)$.

190 See I.R.S. Announcement 2000-51, 2000-22 I.R.B. 1141, 1141-42 (inviting comments on proposed revisions to Circular No. 230).

${ }^{191}$ Letter from James E. Merritt, Chair, American College of Tax Counsel, to Neal Wollin, General Counsel, Department of the Treasury (July 27, 2000), in 2000 TAX NOTES TODAY 158-44, WL 2000 TNT.

${ }_{192}^{193}$ Id. 
sanctions to the practitioner's firm. ${ }^{194}$ It is hoped that these additional sanctions will provide greater flexibility in matching the seriousness of the practitioner's wrongful conduct to the punishment, thereby increasing the likelihood that the practitioner will be sanctioned. ${ }^{195}$

In addition to new sanctions, other proposed revisions relate to the content of tax opinions. Tax opinions that are to be used by taxpayers to meet the reasonable cause exception ("reasonable cause opinions") should be required to "address and opine on the applicability of judicial, statutory and regulatory doctrines that could apply to the tax shelter transaction. "196 The opinion writer should also be required to "undertake an adequate factual inquiry" before rendering such an opinion. ${ }^{197}$

To further protect the reasonable cause exception from tax opinion abuse, separate revisions should apply to tax opinions provided to corporate tax shelter promoters to be used as marketing material. Such opinions should be required to state that they may not be relied upon by a taxpayer for purposes of meeting the reasonable cause exception, should "address all material tax aspects of the proposed transaction, including the judicial, statutory and regulatory doctrines that are required to be addressed in a reasonable cause opinion," and should "be based on a detailed set of hypothetical facts." 198

Adopting the above-suggested revisions should help clarify the requirements a tax opinion must meet before it can be used as a basis for satisfying the reasonable cause exception. In addition, with appropriate publicity regarding the revisions, taxpayers will be more likely to seek their own tax opinions addressed to the specific facts of the transaction that they are contemplating, instead of relying on a generic tax opinion provided to the corporate tax shelter promoter. ${ }^{199}$

${ }^{1} \cdot 4$ Letter from Robert H. Scarborough, Tax Section, New York State Bar Association, to Charles O. Rossotti, Commissioner, Internal Revenue Service, and Jonathan Talisman, Acting Assistant Secretary (Tax Policy), Department of the Treasury (July 31, 2000), in 2000 TAX NOTES TODAY 150-31, WL 2000 TNT 150-31 [hereinafter NXSBA Circular No. 230 letter].

${ }^{145}$ See Letter from Barry Roy, Director for Quality Assurance and Risk Management, Deloitte \& Touche, to Charles O. Rossotti, Commissioner, Internal Revenue Service (Aug. 14, 2000), in 2000 TAX NOTES TODAY 169-19, WL 2000 TNT 169-19 ("The severity of the suspension or disbarrment [sic] sanctions may limit their usefulness in addressing less egregious violations of the Circular 230 standards.").

${ }^{i w_{i}}$ NYSBA Circular No. 230 letter, supra note 194.

I'T Id.

Iax $I d$.

I: At least one commentator has argued that there should be strict liability penal- 
Combining the content revisions with new sanctions should make every tax opinion more valuable in determining the legitimacy of a transaction, which is, after all, the purpose of the tax opinions.

The Compaq case does not deal with this issue directly because no opinion letter was ever obtained in that case. ${ }^{200}$ The court relied on this fact, however, in assessing an understatement penalty, citing it as evidence of the minimal investigation Compaq undertook of the transaction. ${ }^{201}$ Whether the court would have reached a different conclusion with respect to the penalty if Compaq had an opinion letter is unknown, since the court also called attention to the extensive tax knowledge of the Compaq employees involved and indicated that they should have known the transaction was a sham. ${ }^{202}$

Despite the above discussion, an increased penalty would be beneficial when used in combination with increased disclosure. ${ }^{203}$ In this context, the penalty would serve primarily as an incentive for taxpayers to comply with the disclosure requirements, not merely as a deterrent to engaging in corporate tax shelter transactions. Many of the proposals suggest increasing the penalty $20 \%$ (its current level) to $40 \%$, but allowing for it to be reduced to $20 \%$ if the taxpayer properly discloses the suspect transaction. ${ }^{204}$ By disclosing a transaction, therefore, the taxpayer would automatically reduce by $50 \%$ any accuracyrelated penalty it might need to pay if the Commissioner eventually determines that the transaction was illegitimate. If a taxpayer chooses to engage in a transaction that might lead to the imposition of a penalty, the taxpayer will take all reasonable steps to minimize the amount of the eventual penalty, if any. Furthermore, the penalty re-

ties for "[s]ophisticated corporate taxpayers" because they "know exactly what kind of return positions they are taking and should not be able to hide behind lawyers' letterheads." Sheppard, supra note 189, at 20; see also NYSBA Circular No. 230 letter, supra note 194 ("[T] he Tax Section is on record as supporting a 'strict liability' standard for the imposition of penalties in connection with underpayments attributable to tax shelter transactions. Adopting strict liability would eliminate taxpayers' reliance on opinions ... of tax advisors ... as a defense to accuracy-related penalties.").

${ }^{200}$ See Compaq, 113 T.C. at 227 ("If any communications occurred in which consideration was given to the correctness of [Compaq's] tax return position when the return was prepared and filed, [Compaq] has chosen not to disclose those communications.").

${ }^{201} I d$.

${ }^{202} I d$.

${ }^{203}$ See supra Part IV.A (arguing that increased disclosure is crucial to any attempt to deal with the corporate tax shelter problem).

${ }^{204}$ See, e.g., Abusive Tax Shelter Shutdown Act of 1999, H.R. 2255, 106th Cong. (1999) (stating that the understatement penalty rate should be increased to $40 \%$ for corporate tax shelters, but be reduced to $20 \%$ if there is appropriate disclosure); TREASURY WHITE PAPER, supra note 3, at 87 (same). 
duction is simply a "bonus" for complying (as the taxpayer would be legally obligated to do) with the disclosure requirements.

\section{Create Consequences for Promoters, Advisors, and Tax-Indifferent Parties Involved in Tax Shelter Transactions}

Many corporate tax shelters rely on tax-indifferent parties ${ }^{205}$ for their success. $^{206}$ Although the specific transactions can be quite complex, the general idea is to allocate a disproportionate amount of the revenue to the tax-indifferent party and a disproportionate amount of the expenses to the taxpayer that purchased the tax shelter. ${ }^{207} \mathrm{~A}$ taxindifferent party is unconcerned about receiving "extra" income because, by definition, it is not subject to United States tax on the transaction. The tax shelter purchaser, on the other hand, receives extra tax benefits that can be used to reduce its overall tax liability.

The general theme behind proposals relating to tax-indifferent parties is to subject them to tax on any income attributable to their participation in a corporate tax shelter. ${ }^{208}$ As part of this scheme, and owing to the fact that many of these parties are not within reach of the

20 See Revenue Raising Propasals: Hearings Before the Senate Comm. on Finance, 106th Cong. (1999), available at 1999 WL 16946747 [hereinafter Hearings] (testimony of Donald C. Lubick, Assistant Treasury Secretary) ("Tax indifferent parties include foreign persons, tax-exempt organizations, Native American tribal organizations, and taxpayers with loss or credit carry forwards."). Finding a tax-indifferent party willing to participate in a corporate tax shelter should not be hard. For example, consider that currently "[t]here are more than a million tax-exempt organizations in the United States." Barnaby W. Zall, Welcome to Our Board-Oh, by the Way, Now You Owe Taxes, Bus. L. TODAY, Jan./Feb. 2000, at 9, 9.

${ }^{21 * i}$ See, e.g., ACM P'ship v. Comm'r, 157 F.3d 231, 242 (3d Cir. 1998) (noting that one partner in the transaction, a foreign corporation not subject to U.S. tax, was allocated nearly eighty-three percent of the transaction's gain), cert. denied, 526 U.S. 1017 (1999).

See Hearings, supra note 205 (testimony of Donald C. Lubick, Assistant Treasury Secretary) ("[T]ax indifferent parties absorb the taxable income from the transaction, leaving tax losses to be allocated to the corporation."). A greatly simplified example can make this more concrete. Megan, a tax-indifferent party, and Eileen, the tax shelter purchaser, enter into a transaction that requires a total capital contribution of $\$ 100$. Megan contributes $\$ 5$ and Eileen $\$ 95$. In the first year, the transaction generates total income of $\$ 1000$ and total expenses of $\$ 1100$. Megan is allocated $80 \%$ of the income, $\$ 800$, but only $20 \%$ of the expenses, $\$ 220$, for a net profit of $\$ 580$. Eileen is allocated $20 \%$ of the income, $\$ 200$, and $80 \%$ of the expenses, $\$ 880$, for a net loss of $\$ 680$. Megan is not taxed on her "profit" and Eileen has a "loss" of $\$ 680$ that she can use to offset her other income.

${ }^{\prime \prime \prime \prime}$ See, e.g., TREASURY WHITE PAPER, supra note 3, at 108 ("Under the Administration's ... proposal, any income received by a tax-indifferent person with respect to a corporate tax shelter would be taxable to such person."). 
Commissioner, the proposals would make all participants in the tax shelter jointly and severally liable for the tax-indifferent party's tax bill. $^{209}$ The overriding problem with this system is that it is not needed. ${ }^{210}$ Relying on the current judicial doctrines (such as the sham transaction doctrine), the Commissioner, when confronted with an abusive transaction that improperly creates tax benefits for a taxpayer by involving a tax-indifferent party, simply needs to reallocate the income and expenses to reflect the substance of the transaction. ${ }^{211}$ The tax benefits created by the transaction disappear, and the taxpayer pays the substantively appropriate amount of tax. Currently, things do not always work this smoothly, but any shortcomings result, not from a lack of tools available to the Commissioner, but instead from a lack of awareness about particular transactions in which tax-indifferent parties are involved. As already discussed, increased disclosure requirements would obviate the problem. ${ }^{212}$

Another proposal, designed to create consequences for promoters and advisors, ${ }^{213}$ imposes an excise tax on the fees they receive for their corporate tax shelter activities. ${ }^{214}$ The motivation behind an excise tax is that it will discourage promoters and advisors from participating in tax shelters by reducing their profitability. An excise tax on promoters and advisors, therefore, is akin to an accuracy-related penalty on taxpayers, and consequently faces the same problems. ${ }^{215}$ Of particular

${ }^{209}$ See, e.g., id. ("To ensure that a tax is paid, all corporate participants [in the tax shelter] would be made joint and severally liable for the tax.").

${ }_{210}$ See Bankman, supra note 146, at 1795 ("The tax indifferent party provision ... would have its real effect not in the actual taxation of such parties ... but in the joint and several liability provisions, which would place such tax on the domestic participants in a shelter. Recharacterization under existing law has the same effect.").

${ }^{211}$ This principle can be demonstrated by referring to the previous example involving Megan and Eileen, supra note 207. The substance of the transaction is that it produced a net loss of $\$ 100$, which should be allocated $\$ 5$ to Megan and $\$ 95$ to Eileen because of their initial capital contributions. After the reallocation, the transaction is no longer abusive, but instead reflects its substance.

${ }_{212}$ See supra Part IV.A (asserting that increasing disclosure of potentially abusive transactions should permit the Commissioner to more readily attack those transactions that are abusive).

${ }^{213}$ Although the Big Five accounting firms are the leading promoters of tax shelters today, investment banks (such as Twenty-First) and some law firms are also active in the field. See Novack \& Saunders, supra note 7, at 199 (identifying the main parties in the corporate tax shelter arena).

${ }^{214}$ See, e.g., TREASURY WHITE PAPER, supra note 3, at 109 (proposing a twenty-five percent excise tax to be assessed on "the fees earned by promoters and advisors with respect to a corporate tax shelter transaction").

${ }^{215}$ See supra notes $177-80$ and accompanying text (describing problems with increasing penalties as a means to reduce corporate tax shelter activity). 
importance is that it will only be an effective deterrent if the Commissioner is able to readily detect corporate tax shelters, which historically has not been the case. ${ }^{216}$

As with the accuracy-related penalty, however, an excise tax might be used as a means to incentivize promoters and advisors to comply with disclosure requirements (if, in fact, the disclosure requirements applied to them). This would require that all properly disclosed transactions be exempted from the excise tax. Absent an exemption, promoters and advisors would not be anxious to disclose their corporate tax shelter activities because doing so would be the equivalent of telling the government that they owe it money. Financially, the promoters and advisors would be better off leaving it to the government to try to figure out what, if anything, is owed because, like the current corporate tax shelter lottery, the government would undoubtedly come up short. On the other hand, by exempting the disclosed activities, the promoters and advisors would be encouraged to disclose to save themselves a substantial amount of money-equal to the amount of the excise tax, which might be as much as twenty-five percent of all corporate tax shelter fees. ${ }^{217}$

\section{Codify Existing Judicial Doctrines}

Proposals to codify existing judicial anti-tax-avoidance doctrines to disallow the tax benefits created by corporate tax shelters are of limited value considering the success of the Commissioner in using them to challenge such transactions. ${ }^{218}$ Once the Commissioner discovers these transactions, there is normally little evidence for the taxpayer to point to to establish their legitimacy. ${ }^{219}$ Furthermore, there is a con-

216 See supra notes 142-43 and accompanying text (discussing the difficulty the Commissioner currently has in uncovering corporate tax shelter transactions).

217 See supra note 214 and accompanying text (describing the proposed excise tax on corporate tax shelter fees).

218 See, e.g., ACM P'ship v. Comm'r, 157 F.3d 231, 250, 254 (3d Cir. 1998) (disallowing the tax benefits arising from a transaction because it lacked both economic substance and a business purpose), cert. denied, 526 U.S. 1017 (1999); Rice's Toyota World, Inc. v. Comm'r, 752 F.2d 89, 95 (4th Cir. 1985) (same); Compaq Computer Corp. v. Comm'r, 113 T.C. 214, $222-25$ (1999) (same); see also Kies, supra note 180, at 1479 ("Recent applications of [the judicial] doctrines have demonstrated their effectiveness and cast doubt on Treasury's asserted need for additional tools.").

${ }^{219}$ See Gleckman \& Woellert, supra note 144, at 50 ("A lot of the [tax shelters] are premised on the fact that they won't be detected. Once they are, they just don't wash' ...." (quoting John E. Chapoton, a partner at Vinson \& Elkins, LLP)); Lardner, supra note 142, at 49 ("Most shelters ... fail an elementary legal test: They lack any substantial purpose other than the creation of the tax benefit itself."). 
cern that the more the Commissioner is required to rely on specific statutory language in the Code, the greater becomes the opportunity for tax shelter promoters to find new loopholes. ${ }^{220}$

One potential advantage of codification is that it might allow the government to save some of the tremendous costs associated with litigation by reducing the need to litigate tax cases. ${ }^{221}$ Whether litigation would actually decrease, however, is questionable. Under the current system, the Commissioner may rely on the judicial doctrines to disallow claimed tax benefits. ${ }^{222}$ If the taxpayer disagrees, he may go to court and present his arguments as to why the doctrines do not apply at all, or at least not in the manner claimed by the Commissioner, to the particular transaction at issue. Under a system in which those doctrines have been codified, the same opportunity will exist for the taxpayer, except that he will have to argue based on statutory language instead of case law (at least until sufficient time has passed to allow for the development of new case law). ${ }^{223}$

Another potential benefit of codification, related to the previous one, is that it might create greater certainty for taxpayers when they attempt to assess how the tax law will treat a particular transaction. The assumption is that Congress will write new laws that are clear and allow taxpayers to readily determine whether a transaction they are

${ }^{220}$ See Hearings, supra note 205 (testimony of Donald C. Lubick, Assistant Treasury Secretary) ("Bright-line/safe-harbor tests ... encourage aggressive positions and playing the examination lottery.... [A] degree of uncertainty may be useful in discouraging taxpayers from venturing too close to the edge, and thereby going over the edge, of established principles."); Gleckman \& Woellert, supra note 144 , at 50 ("[A] statute runs the risk of reopening loopholes the courts have been closing.... [I]t would do little more than provide a new roadmap for circumventing the law."). But see Springsteel, supra note 7 ("Taxpayers would be better off if Treasury had more resources, in order to create a clearer line through more guidance. After all, what's wrong with a clear line, as long as you're on the right side of it?"' (quoting Edward Kleinbard, a partner at Cleary, Gottlieb, Steen \& Hamilton)).

${ }^{221}$ The relevant argument suggests that taxpayers would be less likely to contest the Commissioner's position if he were relying on the explicit language of the Code instead of an interpretation of a judicial opinion. See Bankman, supra note 146, at 1788 ("Courts give much greater deference to a position clearly incorporated in regulations than the same position supported only by an interpretation of case law.").

${ }^{222}$ See Kies, supra note 180 , at 1478 ('Pursuant to several 'common-law' tax doctrines, Treasury and the Service have the ability to challenge taxpayer treatment of a transaction that they believe is inconsistent with statutory rules and the underlying congressional intent.").

${ }^{223}$ See Lee A. Sheppard, Whistling Dixie About Comporate Tax Shelters, 85 TAX NotEs 569,570 (1999) (noting that corporate tax shelter purchasers "might carry on investing in shelters while litigating the new legal questions presented by the government's wish list of proposals”). 
considering is legitimate, or instead, an illegitimate corporate tax shelter. An initial problem with this assumption is that it relies on Congress to write clear and unambiguous statutes that are neither too broad, and thus an impediment to legitimate transactions, nor too narrow, and thus ineffective. Furthermore, would existing case law be supplanted, or merely supplemented, by such statutes? If the answer is supplanted, that places far more reliance on Congress's ability to write statutes with the appropriate scope because there will be no alternative means of enforcement. If the answer is merely supplemented, what purpose does the codification serve?

Finally, although the current judicial doctrines may not always produce the quick and easy answer some people would desire, they do provide a well developed framework to guide any analysis. ${ }^{224}$ Gray areas definitely exist in the case law, ${ }^{225}$ as they would in any reasonable codification, but corporate tax personnel can assess the merits of most products offered by corporate tax shelter promoters. ${ }^{226}$ In Compaq, for example, the Tax Court made it quite clear that the taxpayer should have been able to determine that the ADR transaction was a sham transaction.

\section{CONCLUSION}

There is no question that corporate tax shelters are a growing concern in the United States. Promoters and advisors expend large amounts of resources to develop and market the tax shelters, and in exchange they receive substantial fees from corporate purchasers anxious to reduce their tax bills. Recent court cases give only a glimpse of the industry, its "products," and the effect on the federal treasury.

What action, if any, Congress will take to deal with the problem remains to be seen. Treasury has taken the most important step by issuing temporary and proposed regulations that require disclosure of potential tax shelter transactions; increased disclosure should allow

${ }^{224}$ See, e.g., supra Part II (describing the analysis that occurs under the sham transaction doctrine).

${ }_{22 z}$ See, e.g., supra Part II.A.1.b (examining whether profit potential should be determined on a present value basis).

szii See Bankman, supra note 146, at 1793 ("[T] he [judicial] doctrines as applied have played a quite useful role.... Practitioners have understood the judicial application of those doctrines-understood in the sense of sharing a consensus as to which transactions are apt to be successfuly [sic] challenged under those doctrines.").

${ }_{227}$ See Compaq Computer Corp. v. Comm'r, 113 T.C. 214, 227 (1999) (stating that the taxpayer's employees involved in the ADR transaction "should have been alerted to the questionable economic nature of the ADR transaction"). 
the Commissioner to concentrate his resources on evaluating the legitimacy of the suspect transactions, instead of searching aimlessly for them. While the debate continues about what other steps, if any, to take, it is an excellent opportunity to observe what impact the temporary and proposed regulations will have.

Even if the temporary and proposed regulations ultimately lead to the demise of corporate tax shelters, there is a substantial amount of money at stake, and it is unlikely that the industry and its customers will go away without a struggle. In the past, the Commissioner has successfully used judicially created tax-avoidance doctrines such as the sham transaction doctrine to combat abusive tax shelters, once they were discovered, and he will continue to do so in the future. 